\title{
Inter-comparison of laboratory smog chamber and flow reactor systems on organic aerosol yield and composition
}

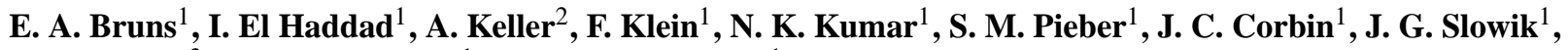 \\ W. H. Brune ${ }^{3}$, U. Baltensperger ${ }^{1}$, and A. S. H. Prévôt ${ }^{1}$ \\ ${ }^{1}$ Laboratory of Atmospheric Chemistry, Paul Scherrer Institute, Villigen, Switzerland \\ ${ }^{2}$ Institute for Aerosol and Sensor Technology, University of Applied Sciences, Northwestern Switzerland, \\ Windisch, Switzerland \\ ${ }^{3}$ Department of Meteorology, Pennsylvania State University, University Park, Pennsylvania, USA \\ Correspondence to: E. A. Bruns (emily.bruns@psi.ch) or A. S. H. Prévôt (andre.prevot@psi.ch)
}

Received: 30 November 2014 - Published in Atmos. Meas. Tech. Discuss.: 8 January 2015

Revised: 30 April 2015 - Accepted: 7 May 2015 - Published: 4 June 2015

\begin{abstract}
A variety of tools are used to simulate atmospheric aging, including smog chambers and flow reactors. Traditional, large-scale smog chambers age emissions over the course of hours to days, whereas flow reactors rapidly age emissions using high oxidant concentrations to reach higher degrees of oxygenation than typically attained in smog chamber experiments. The atmospheric relevance of the products generated under such rapid oxidation warrants further study. However, no previously published studies have compared the yields and chemical composition of products generated in flow reactors and smog chambers from the same starting mixture.

The yields and composition of the organic aerosol formed from the photo-oxidation of $\alpha$-pinene and of woodcombustion emissions in a smog chamber (SC) and two flow reactors: a potential aerosol mass reactor (PAM) and a microsmog chamber (MSC), were determined using aerosol mass spectrometry. Reactants were sampled from the SC and aged in the MSC and the PAM using a range of hydroxyl radical $(\mathrm{OH})$ concentrations and then photo-chemically aged in the SC.

The chemical composition, as well as the maximum yields and emission factors, of the products in both the $\alpha$-pinene and wood-combustion systems determined with the PAM and the $\mathrm{SC}$ agreed reasonably well. High $\mathrm{OH}$ exposures have been shown previously to lower yields by breaking carboncarbon bonds and forming higher volatility species, which reside largely in the gas phase; however, fragmentation in the PAM was not observed. The yields determined using the
\end{abstract}

PAM for the $\alpha$-pinene system were slightly lower than in the SC, possibly from increased wall losses of gas phase species due to the higher surface area to volume ratios in the PAM, even when offset with better isolation of the sampled flow from the walls. The $\alpha$-pinene SOA results for the MSC were not directly comparable, as particles were smaller than the optimal AMS transmission range. The higher supersaturation in the flow reactors resulted in more nucleation than in the SC. For the wood-combustion system, emission factors measured from the MSC were typically lower than those measured from the SC. Lower emission factors in the MSC may have been due to considerable nucleation mode particles formed in the MSC which were not detected by the AMS or due to condensational loss of gases to the walls inside or after the MSC. More comprehensive coverage of the potential particle size range is needed in future SOA measurements to improve our understanding of the differences in yields when comparing the MSC to the SC. The PAM and the SC agreed within measurement uncertainties in terms of yields and composition for the systems and conditions studied here and this agreement supports the continued use of the PAM to study atmospheric aging.

\section{Introduction}

The complex mixture and constant transformation of compounds in the atmosphere is a major challenge for complete aerosol characterization. Studying simplified systems in the 
laboratory greatly improves our understanding of the chemical and physical properties of primary emissions and secondary products formed during atmospheric processing. Secondary organic aerosol (SOA), formed from the oxidation and condensation of gas phase species, is a large fraction of the submicron aerosol measured in the atmosphere (Zhang et al., 2007) and is of importance in understanding the impacts of aerosols on health (Pope and Dockery, 2006; Baltensperger et al., 2008), climate (IPCC, 2013) and visibility (Went, 1960). Several tools are used to simulate atmospheric aging, including smog chambers (e.g., Cocker et al., 2001; Paulsen et al., 2005; Rohrer et al., 2005; Lee et al., 2009; Presto et al., 2011; Platt et al., 2013) and flow tube reactors (e.g., Bertram et al., 2001; Esteve et al., 2004; George et al., 2007; Hearn and Smith, 2007; Kang et al., 2007; McNeill et al., 2008; Smith et al., 2009; Ezell et al., 2010; Lambe et al., 2011a; Keller and Burtscher, 2012). These techniques allow for aging under a variety of conditions (e.g., different temperatures, relative humidity, light sources and oxidants) and on varying timescales. Smog chambers, which range in size from a few liters to $270 \mathrm{~m}^{3}$ (Rohrer et al., 2005), allow for the simulation of aging on the order of hours to days in the atmosphere when operated in batch mode. In comparison, flow tube reactors, which range in size from less than $0.1 \mathrm{~L}$ to over $1 \mathrm{~m}^{3}$ (Ezell et al., 2010; Keller and Burtscher, 2012), typically operate on relatively short timescales with high oxidant concentrations allowing for higher degrees of aging in a shorter time period than possible in traditional smog chambers.

Smog chambers and flow reactors are each subject to unique limitations. Traditional smog chamber experiments are often unable to achieve the degree of oxygenation observed in the atmosphere ( $\mathrm{Ng}$ et al., 2010). This limitation is due to high SOA precursor concentrations and/or insufficient oxidant exposure (concentration $\times$ time) compared to the atmosphere. Also, smog chambers and large flow reactors are typically stationary, making it necessary to perform experiments in a single location. This restriction is not practical for studying emissions from large-scale devices, such as aircraft or ship engines, although recent efforts have been made to mobilize medium-scale chambers (Presto et al., 2011; Platt et al., 2013).

Portable flow reactors are an attractive tool for simulating atmospheric aging at different locations. However, smaller flow reactors utilize oxidant concentrations that are much higher than those typically observed in the atmosphere to simulate days of atmospheric aging within seconds to minutes, and the relevance of such rapid aging to atmospheric processes needs further investigation. Although the reaction kinetics of heterogeneous $\mathrm{OH}$ oxidation of squalane and 2octyldodecanoic acid have been shown to be independent of $\mathrm{OH}$ concentration and time, as long as the same $\mathrm{OH}$ exposure is achieved (Renbaum and Smith, 2011), the OH concentration may be important in SOA formation due to kinetic competition between gas-particle partitioning and fur- ther gas phase oxidation. High oxidant concentrations may result in underestimated SOA yields in flow reactors due to an increased importance of fragmentation reactions (carboncarbon bond breakage leading to higher volatility products and loss of aerosol mass) relative to functionalization reactions (addition of oxygen leading to lower volatility products and increased aerosol mass) (Kroll et al., 2009; ChaconMadrid and Donahue, 2011; Lambe et al., 2012). Finally, flow reactors typically have higher surface area to volume (SA / V) ratios compared to smog chambers, which can result in significantly higher losses of material to the walls, depending on reactor design. At the same time, the lower residence times and reduced convective mixing in flow reactors present an opportunity for better isolation of the sampled flow from the flow near the walls.

The potential aerosol mass reactor (PAM) is a flow reactor that has been used to study SOA formation from a variety of atmospherically relevant systems and emission sources (Kang et al., 2007, 2011; Massoli et al., 2010; Cubison et al., 2011; Lambe et al., 2011a, 2012, 2013, 2015; Bahreini et al., 2012; Saukko et al., 2012; Wang et al., 2012; Chen et al., 2013; Li et al., 2013; Ortega et al., 2013; Tkacik et al., 2014; Chhabra et al., 2015). Previous work has investigated yields and elemental composition of SOA generated from the oxidation of individual SOA precursors such as $\alpha$-pinene in the PAM (Kang et al., 2007; Lambe et al., 2011a, 2015; Chen et al., 2013; Chhabra et al., 2015). Results were compared to previously published smog chamber experiments; however, conditions varied between the PAM and smog chambers (e.g., presence of seed aerosol). Although the composition of SOA produced in the PAM from $\alpha$-pinene, $m$-xylene and $p$-xylene has been shown to resemble that of oxygenated organic aerosol measured in the ambient (Massoli et al., 2010; Kang et al., 2011), questions remain on the comparability of these different aging techniques for SOA yields and chemical composition, particularly for more complex mixtures.

Recently, a micro-smog chamber (MSC) was designed for real-time monitoring of the SOA production potential during emissions testing of combustion systems (Keller and Burtscher, 2012). The MSC was designed to sample under high concentration, "plume-like" conditions; however, emissions are often diluted to atmospherically relevant concentrations for other experimental aspects and the performance of the MSC under these more dilute conditions is unknown. Also, yields determined using the MSC have not been compared to yields determined using smog chambers or other flow reactors measuring the same emissions. The chemical composition of SOA generated in the MSC remains to be investigated.

We compare aerosol yields and chemical composition from the photo-oxidation of residential wood-combustion emissions and of $\alpha$-pinene using a $7 \mathrm{~m}^{3}$ smog chamber (SC), a PAM and an MSC across a range of $\mathrm{OH}$ exposures. High-resolution time-of-flight aerosol mass spectrometer (AMS) measurements provided insight into particulate 
chemical composition and a proton transfer reaction time-offlight mass spectrometer (PTR-MS) was used to determine $\mathrm{OH}$ exposures for comparison of the different reactors.

\section{Methods}

\subsection{Smog chamber and flow reactors}

The original concept of the PAM is described by Kang et al. (2007), and the PAM used here is an earlier version of the one described by Lambe et al. (2011a). Briefly, this version of the PAM is a single, $0.015 \mathrm{~m}^{3}$ cylindrical glass chamber ( $0.46 \mathrm{~m}$ length, $0.22 \mathrm{~m}$ diameter) flanked by two UV lamps (185 and $254 \mathrm{~nm}$ emission lines, BHK Inc.), which were cooled by a constant flow of pure air ( 250 series, Aadco Instruments, Inc.). Prior to entering the PAM, humidified pure air $\left(1 \mathrm{~L} \mathrm{~min}^{-1}\right.$, Nafion membrane, Perma Pure LLC) was merged with the incoming reactant flow to provide sufficient $\mathrm{H}_{2} \mathrm{O}$ for $\mathrm{OH}$ formation. In the PAM, $\mathrm{O}_{3}$ generated by the lamps undergoes photolysis to form $\mathrm{O}\left({ }^{1} \mathrm{D}\right)$, which reacts with $\mathrm{H}_{2} \mathrm{O}$ to form $\mathrm{OH}$. The $\mathrm{OH}$ concentration was adjusted by varying the light intensity. Hereafter, $\mathrm{PAM}_{\text {high }}$ corresponds to the maximum light intensity and $\mathrm{PAM}_{\mathrm{low}}$ corresponds to a light intensity of $\sim 70 \%$ of the maximum. The incoming reactant flow was radially dispersed in the PAM by passage through a perforated mesh screen at the inlet flange. To reduce interactions with the wall, air was sampled along the center of the chamber $\left(\sim 2 \mathrm{~L} \mathrm{~min}^{-1}\right)$ as well as along the perimeter of the chamber $\left(\sim 6 \mathrm{~L} \mathrm{~min}^{-1}\right)$. Instruments sampled from the inner sample flow only and the outer ring flow was discarded. The total flows through the PAM were constant, giving a gas phase half-life of $53 \pm 10 \mathrm{~s}$. All reported deviations are two standard deviations ( $2 \mathrm{~s})$ of the measurements. The temperature in the PAM was likely slightly higher than ambient due to heating from the lamps; however, products cooled during transport from the PAM to the AMS. As no direct temperature measurements were made, no temperature correction was applied to the yields.

The MSC is described in detail by Keller and Burtscher (2012). Briefly, the MSC is composed of two $76 \mathrm{~mL}$ cylindrical quartz chambers $(0.25 \mathrm{~m}$ length, $0.02 \mathrm{~m}$ diameter) in series. As in the PAM, OH radical is generated from the photolysis of $\mathrm{O}_{3}$ in the presence of $\mathrm{H}_{2} \mathrm{O}$. The incoming sample was exposed to UVC (ultraviolet-C) light (5 total lamps at $4 \mathrm{~W}$ each; 185 and $254 \mathrm{~nm}$ emission lines; Heraeus, type GPH212T5VH/2) in the first chamber and to UVA (ultraviolet-A) light (Panacol-Elosol, type UV-H 255) in the second chamber. The light intensity was varied during the experiments by adjusting the number of UVC lights used denoted as $\mathrm{MSC}_{\text {low }}$ (1 light on), $\mathrm{MSC}_{\text {mid }}$ (3 lights on) and $\mathrm{MSC}_{\text {high }}$ (5 lights on). The total flow rate through the MSC was constant at $1.2 \mathrm{~L} \mathrm{~min}^{-1}$, giving a gas phase halflife of $13 \pm 2 \mathrm{~s}$, except in experiment 5 (Table 1) where the

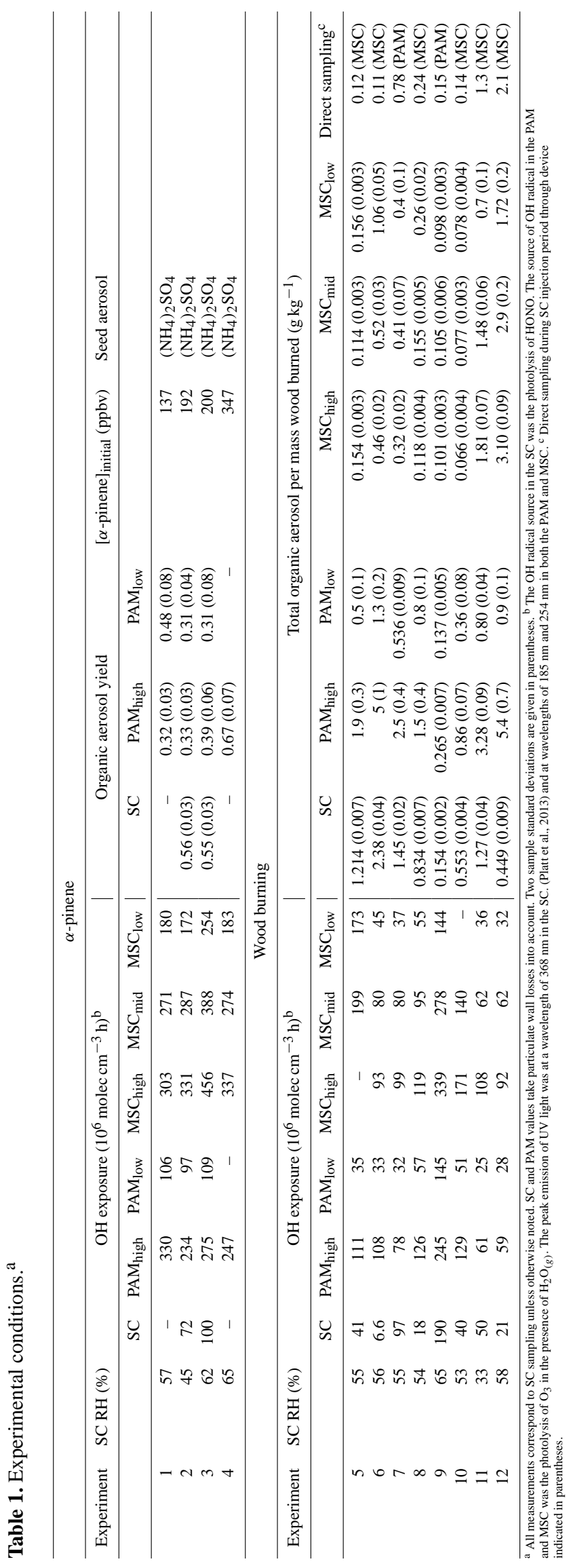

Atmos. Meas. Tech., 8, 2315-2332, 2015 
flow rate was $0.7 \mathrm{~L} \mathrm{~min}^{-1}$. As with the PAM, no temperature correction to the yields was applied.

The smog chamber, similar to the one described by Platt et al. (2013), was located inside temperature-controlled housing to maintain a constant temperature in all experiments ( $292 \pm 2 \mathrm{~K})$. The smog chamber was flanked by 4 sets of 10 UV lights (90-100 W, Cleo Performance, Philips).

The PAM and MSC were cleaned prior to each experiment by flushing with pure air (dry air in the MSC and humidified air in the PAM) while irradiating with UV light. The $\mathrm{SC}$ was cleaned prior to each experiment by filling with humidified air and $\mathrm{O}_{3}$ and irradiating with UV light for at least $1 \mathrm{~h}$, followed by flushing with dry, pure air for at least $10 \mathrm{~h}$. After cleaning, the SC was partially filled with humidified pure air and $d 9$-butanol (butanol-D9, $98 \%$, Cambridge Isotope Laboratories). Using a rate constant with respect to $\mathrm{OH}$ of $3.4 \times 10^{-12} \mathrm{~cm}^{3} \mathrm{molec}^{-1} \mathrm{~s}^{-1}$ (Barmet et al., 2012), $\mathrm{OH}$ exposures were calculated by monitoring the decay of $d 9$ butanol $\left(\left[\mathrm{M}+\mathrm{H}-\mathrm{H}_{2} \mathrm{O}\right]^{+}\right.$fragment, $\left.m / z 66\right)$ using a PTR-MS $\left(\left[\mathrm{H}_{2} \mathrm{O}+\mathrm{H}\right]^{+}\right.$reagent ion, Ionicon Analytik). Unlike in the PAM and MSC, $\mathrm{OH}$ in the SC was formed from the photolysis of nitrous acid (HONO), as described below. Without the injection of HONO, similar OH exposures in the SC and flow reactors were not achieved within the experimental time frame dictated by the chamber size.

When the reactants were sampled directly from the SC through the flow reactors, the dilution ratios were identical for the MSC and the SC. The small additional flow of humidified air into the PAM resulted in a $\sim 15 \%$ dilution of the reactants, which was accounted for when calculating yields and emission factors. The additional dilution step in the PAM may shift the partitioning of the incoming semivolatile species towards the gas phase. However, once inside the PAM, these semi-volatile, gas phase species are expected to repartition to the particle phase as they undergo oxidation to form lower volatility species and thus yields and emission factors were likely not affected.

The flow reactors use lower wavelength/more intense UV lamps than the SC and this could influence aerosol yields in both the $\alpha$-pinene and wood-burning experiments by altering the product volatility distribution. For example, Presto et al. (2005) found that yields from $\alpha$-pinene oxidation were reduced by $20-40 \%$ in the presence of UV light compared to dark conditions (i.e., ozonolysis) due to the photolysis of species prior to partitioning to the aerosol phase. However, Hodzic et al. (2015) calculated that the gas phase photolysis of species formed during the photo-oxidation of $\alpha$-pinene ( $\alpha$-pinene $/ \mathrm{NO}_{x}$ ratio of $\sim 0.1$ ) decreased the SOA yield by only $\sim 15 \%$ and there was negligible effect on the bulk particulate oxygen-to-carbon ratio. Although $\mathrm{O}_{3}$ was not measured in the current experiments and $\mathrm{OH}$ radical is expected to be the main oxidant in all systems, it is possible that the relative amount of ozonolysis relative to $\mathrm{OH}$ oxidation varied between the devices, which would also influence relative yields.

\subsection{Wood combustion}

The experimental set-up is shown in Fig. 1. As described in detail below, experiments began with the injection of the wood-combustion emissions into the SC with concurrent sampling through either the PAM or MSC ("direct sampling”). After filling the SC, primary emissions were characterized in the SC followed by sampling the primary emissions from the SC through the flow reactors ("SC sampling"). Finally, emissions were aged in the SC.

Combustion occurred in a modern log-wood burner (Avant, Attika) using an average of $3 \pm 1 \mathrm{~kg}$ of beech wood (3-4 logs, 4-5 pieces of kindling and 3 fire starters comprised of pine wood shavings, paraffin and natural resin). After a burning period of 15-30 min to allow the fire to reach stable burning conditions, emissions were sampled from the chimney, diluted using an ejection diluter (DI-1000, Dekati Ltd.) and injected into the SC (Fig. 1) for 9-26 min. The diluter and the sample line from the chimney to the diluter were held at $473 \mathrm{~K}$ and the sample line between the diluter and the $\mathrm{SC}$ was held at $423 \mathrm{~K}$ to minimize condensational losses of the hot emissions. After emission injection, the relative humidity (RH) in the SC ranged from 33-65\% (Table 1). During the injection period, gas phase compounds were measured after a second ejector diluter (DI-1000, Dekati Ltd.) using a $\mathrm{CO}_{2} / \mathrm{CO} / \mathrm{CH}_{4} / \mathrm{H}_{2} \mathrm{O}$ analyzer (Picarro, Inc.), a $\mathrm{NO}_{x}$ $\left(\mathrm{NO}+\mathrm{NO}_{2}\right)$ analyzer $(42 \mathrm{C}$, trace level, Thermo Environmental Instruments) and a total hydrocarbon (THC) analyzer (APHA-370, Horiba Ltd.) to determine the dilution factor into the SC. A particulate filter at ambient temperature was located upstream of the gas phase instruments. Total dilution factors of the raw emissions in the SC ranged from $\sim 100$ 250.

During SC filling, either the PAM or MSC concurrently sampled the emissions, referred to as direct sampling. During MSC direct sampling, emissions were sampled from the sample line used for smog chamber injection (factor of $\sim 9$ dilution of the raw emissions into the MSC). After oxidation in the MSC, the sample was diluted by an additional factor of $22 \pm 3$ with pure air using a rotating disc diluter. Rotating disc diluter dilution ratios were determined by measuring $\mathrm{CO}_{2(g)}$ before (Carbondio-002, Pewatron AG) and after (LI-7000, LI-COR, Inc.) the rotating disc diluter. As these measurements were not made during experiments 5 and 6 , the average dilution ratio from the other experiments was applied to these experiments. The $\mathrm{OH}$ exposures during direct sampling are not known, but may be substantially lower than when sampling from the SC due to higher reactant concentrations in the MSC. For PAM direct sampling, emissions were sampled from the same sample line as the smog chamber injection and then diluted in a second ejector diluter (DI-1000, Dekati Ltd.) at ambient temperature before entering the reactor. Emissions into the PAM were diluted by a total factor of $\sim 150$, similar to that of the SC. Despite differences in the dilution factors in the $\mathrm{SC}$ and flow reactors during direct 


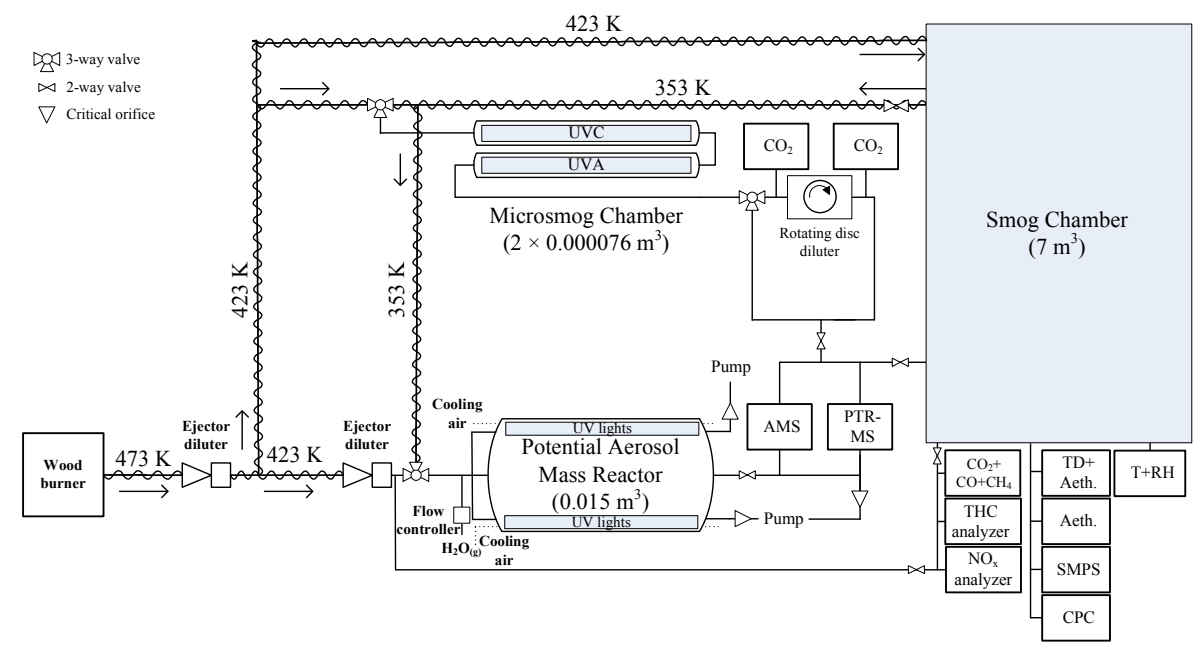

Figure 1. Experimental design for wood-combustion experiments (not drawn to scale). Emissions were sampled through the PAM or MSC, either from the wood burner or from the SC after emission injection. The rotating disc diluter after the MSC and the second ejector diluter before the PAM were only used when sampling from the burner. AMS and PTR-MS measurements alternated among the three systems. TD refers to the thermal desorber upstream of one Aethalometer.

sampling, useful information can be gained during the direct sampling, particularly for the MSC as it was operated under the conditions for which it was designed. After oxidation in either flow reactor, the aged products were characterized using an AMS as described below and a PTR-MS.

After the emissions were injected into the SC, nonrefractory particle mass, chemical composition and size measurements were made using a high-resolution time-of-flight AMS with a standard inlet lens (Aerodyne Research, Inc.) (DeCarlo et al., 2006). Based on the results of several previous wood-combustion measurements, the AMS collection efficiency was assumed to be 1 (Hennigan et al., 2011; Heringa et al., 2011; Eriksson et al., 2014). Equivalent black carbon (EBC) mass loadings were determined using two Aethalometers (AE33, Magee Scientific Company). A thermal desorber comprised of a $50 \mathrm{~cm}$ heating section held at $423 \mathrm{~K}$ followed by a $50 \mathrm{~cm}$ denuder section was placed directly upstream of one Aethalometer to volatilize and remove organic species (Burtscher et al., 2001). A condensation particle counter (CPC, 3776 TSI) measured total particle number concentrations and a scanning mobility particle sizer (SMPS; CPC 3776 and DMA 3081 TSI Inc.) measured particle size distributions. Particles were dried (Nafion membrane, Perma Pure LLC) upstream of the AMS. Gas phase compounds were characterized using the PTR-MS, $\mathrm{CO}_{2} / \mathrm{CO} / \mathrm{CH}_{4} / \mathrm{H}_{2} \mathrm{O}$ analyzer, $\mathrm{NO}_{x}$ analyzer and THC analyzer described above.

After characterizing the primary emissions in the SC, both the PAM and MSC sampled the primary emissions from the $\mathrm{SC}$, referred to as "SC sampling". To minimize losses, the sample line between the SC and flow reactors was heated to $353 \mathrm{~K}$. During SC sampling, the rotating disc diluter and ejector diluter were not used.
After measuring from the SC with the flow reactors, nitrous acid (HONO) in $\mathrm{N}_{2}\left(2.0-2.7 \mathrm{~L} \mathrm{~min}^{-1}, 5.0\right.$, Messer) was continuously injected into the $\mathrm{SC}$ to provide an $\mathrm{OH}$ source when the SC lights were turned on. Nitrous acid was generated by bubbling $\mathrm{N}_{2}$ though a mixture of $\mathrm{H}_{2} \mathrm{SO}_{4}$ (95-97\%, Merck) in water $(10 \mathrm{mM}, 18.0 \mathrm{M} \Omega \mathrm{cm}$, MilliQ, Reference $\mathrm{A}+)$ and $\mathrm{NaNO}_{2}(4 \mathrm{mM}, \geq 99.0 \%$, Fluka) in water. The resulting mixture was passed through a particle filter and injected into the chamber (Taira and Kanda, 1990; Pfaffenberger et al., 2013). Emissions were then aged in the $\mathrm{SC}$ for $\sim 2-4 \mathrm{~h}$. Exposures from $\mathrm{OH}$ ranged from $(0-1.9) \times 10^{8}$ molec $\mathrm{cm}^{-3} \mathrm{~h}$ in the $\mathrm{SC}$, to $(0.25-2.5) \times 10^{8}$ molec $\mathrm{cm}^{-3} \mathrm{~h}$ in the PAM and to $(0.32$ $3.4) \times 10^{8} \mathrm{molec}^{-3} \mathrm{~h}$ in the MSC (Table 1). At an atmospheric $\mathrm{OH}$ concentration of $1 \times 10^{6}$ molec $\mathrm{cm}^{-3}$, this corresponds to aging in the atmosphere on the order of 0-8 days in the SC, 1-10 days in the PAM and 1-14 days in the MSC. When sampling through the flow reactors, HONO was not injected; however, as significant concentrations of $\mathrm{NO}_{x}$ are emitted during wood combustion, this additional source of $\mathrm{NO}_{x}$ is not expected to influence the results significantly. Initial $\mathrm{NO}_{x}$ mixing ratios in the $\mathrm{SC}$ prior to aging are presented in Table S1 in the Supplement.

\section{$2.3 \alpha$-Pinene oxidation}

During $\alpha$-pinene photo-oxidation experiments, seed aerosol was injected into the humidified chamber (Table 1). Seed aerosol was generated by nebulizing a solution of $\left(\mathrm{NH}_{4}\right) \mathrm{HSO}_{4}$ in water $(10 \mathrm{mM})$ and injected into the chamber to reach concentrations of $\sim 10-60 \mu \mathrm{g} \mathrm{m}^{-3}$. Then, $\alpha$-pinene (98\%, Sigma-Aldrich) was injected into the SC through a heated injection system $(353 \mathrm{~K})$ to give mixing ratios of 
137-347 ppbv, measured using the PTR-MS. After the injection and mixing of $\alpha$-pinene and seed aerosol in the $\mathrm{SC}$, the mixture was sampled from the SC into the PAM or the MSC. Oxidation of the mixture in the flow reactors occurred in the same manner as oxidation of woodcombustion emissions during SC sampling. After sampling through the flow reactors, a continuous HONO injection was started as described for the wood-combustion experiments and the SC UV lights were turned on for $\sim 2-3 \mathrm{~h}$. The AMS and PTR-MS measured from each device and additionally, the SMPS measured from the SC. The AMS collection efficiency was assumed to be 1 in all experiments. Exposures to $\mathrm{OH}$ ranged from $(0-1.0) \times 10^{8} \mathrm{molec}^{-3} \mathrm{~h}$ in the SC, $(0.97-3.3) \times 10^{8}$ molec $^{-3} \mathrm{~h}$ in the PAM and (1.74.6) $\times 10^{8}$ molec $\mathrm{cm}^{-3} \mathrm{~h}$ in the MSC. At an atmospheric $\mathrm{OH}$ concentration of $1 \times 10^{6}$ molec $\mathrm{cm}^{-3}$, this corresponds to aging in the atmosphere on the order of 0-4 days in the SC, 4-14 days in the PAM and 7-19 days in the MSC.

The injection of HONO into the SC resulted in NO formation upon irradiation, which was not present in the flow reactors, and may decrease the SOA yields in the $\mathrm{SC}(\mathrm{Ng}$ et al., 2007). When maximum $\mathrm{SOA}$ yields were reached, $\mathrm{NO}_{x}$ mixing ratios in experiments 2 and 3 were $\sim 100$ and $120 \mathrm{ppbv}$, respectively (Fig. S1 in the Supplement). Ng et al. (2007) found that SOA yields from $\alpha$-pinene photo-oxidation were decreased by $\sim 40 \%$ in the presence of an initial $\mathrm{NO}_{x}$ mixing ratio of $198 \mathrm{ppbv}$. However, in our study, $\alpha$-pinene $/ \mathrm{NO}_{x}$ ratios were 20-25 times higher than those used by $\mathrm{Ng}$ et al. (2007) and they started with high levels of $\mathrm{NO}_{x}$ whereas here initial $\mathrm{NO}_{x}$ concentrations were 0 . Thus, the reduction in yields due to the presence of $\mathrm{NO}_{x}$ is expected to be lower than observed by $\mathrm{Ng}$ et al. (2007). The temporal evolution of $\mathrm{NO}_{x}$ and organic aerosol (OA) in the SC throughout aging is shown in Fig. S1. As observed in previous studies (Chhabra et al., 2011; Lambe et al., 2015), no differences in the bulk aerosol composition are expected due to the presence/absence of $\mathrm{NO}_{x}$.

\subsection{Wall losses}

Smog chambers and flow reactors suffer from the loss of particulate and gaseous material to the walls to varying degrees (McMurry and Rader, 1985; Zhang et al., 2014). Minimizing surface area to volume ratios, using inert wall materials and attempting to isolate the sampled flow from the walls help reduce losses, but challenges remain. As shown by Zhang et al. (2014), wall losses of semi-volatile species are particularly difficult to quantify and were not corrected for here in either flow reactor or the SC. Corrections for losses due to impaction of particles on the walls in each system were estimated independently for the different systems as follows. Wall losses of particles in the SC were accounted for using the method described in Weitkamp et al. (2007), assuming all particles were lost equally to the walls and that condensable material partitioned only to suspended particles. Partic- ulate wall-loss rates were determined using the decay of EBC measured after the thermal desorber at the end of the experiment for the wood-combustion experiments and the decay of particulate organic mass at the end of the $\alpha$-pinene experiments. PTR-MS analysis showed that $>99 \%$ of the $\alpha$ pinene reacted before the period in which the wall-loss rate was determined. The particulate half-lives in the SC were $1.7 \pm 0.2 \mathrm{~h}$ for $\alpha$-pinene experiments and $4 \pm 1 \mathrm{~h}$ for woodcombustion experiments. The difference in particle half-lives between the systems was largely due to differences in particle sizes. After aging in the SC, the mode of the SMPS number based size distribution for the wood-combustion experiments was $\sim 250 \mathrm{~nm}$, compared to only $\sim 100 \mathrm{~nm}$ for the $\alpha$ pinene experiments. As diffusional losses of particles scale with the square root of diameter, particle losses due to diffusion are expected to be $\sim 1.6$ times higher than in the woodcombustion experiments (McMurry and Grosjean, 1985).

Particle wall losses in the PAM have been quantified previously (Lambe et al., 2011a), but not yet with an analysis similar to Zhang et al. (2014), which takes into account the loss of semi-volatile gases. As described earlier, the ring flow in the PAM provides a barrier between the sample flow and the wall, thus reducing particulate losses to the walls. The PAM aerosol yields reported in this study (Table 1) account for particulate wall losses using the size-dependent transmission efficiency data from Lambe et al. (2011a). As mobility diameter measurements were not available, this correction was performed by converting vacuum aerodynamic diameters $\left(d_{\mathrm{va}}\right)$ measured by the AMS to mobility diameters (DeCarlo et al., 2004), assuming spherical particles and an organic aerosol density of $1.2 \mathrm{~g} \mathrm{~cm}^{-3}$ (Turpin and Lim, 2001). For comparison, yields without accounting for particulate wall losses in the PAM are reported in Table S2. When AMS size distribution data were not available, an average correction factor from the other experiments from the same system was applied. For the $\alpha$-pinene system, yields increased by a factor of 1.42 and for the wood-combustion experiments, yields increased by an average factor of $1.31 \pm 0.04$ (Table S2) when accounting for PAM particulate wall losses. Reported MSC yields do not take into account losses of particles to the walls; however, Keller and Burtscher (2012) calculated diffusional losses to be $\sim 11 \%$ for $10 \mathrm{~nm}$ diameter particles and $<1 \%$ for $100 \mathrm{~nm}$ particles due to the low residence time in the device.

\subsection{Yields/emission factors}

OA yields from the $\alpha$-pinene oxidation experiments were calculated by dividing the amount of OA formed during aging by the amount of reacted $\alpha$-pinene. The total OA formed per mass wood burned (referred to hereafter as an emission factor, although the total OA is taken after aging of the emissions) was determined for each wood-combustion experiment. The amount of wood burned was calculated using a 
carbon balance approach described previously (Andreae and Merlet, 2001; Bruns et al., 2015).

\subsection{Wood-combustion product composition}

Bulk aerosol composition was influenced by the chemical transformations of the reactants in each device as well as by the ratio of primary to secondary products. To separate the effects of chemistry and yields on the composition, the primary organic aerosol (POA) and SOA components measured after each device were separated using positive matrix factorization (PMF). PMF represents a mass spectral time series as a linear combination of static factor profiles (i.e., mass spectra) and their time-dependent intensities (Paatero and Tapper, 1994; Paatero, 1997) and has been widely applied to AMS ambient and smog chamber data (Lanz et al., 2007; Zhang et al., 2011; Craven et al., 2012). In the present study, PMF was used to extract a POA mass spectrum and its associated time series for each experiment. The POA contribution was then subtracted from the mass spectral time series, and the remainder was assumed to be SOA. PMF was implemented using the Multilinear Engine (ME-2) (Paatero, 1999), with model configuration and data analysis performed with the source finder (SoFi) toolkit (Canonaco et al., 2013) for the Igor Pro software environment (WaveMetrics, Inc.). In contrast to conventional PMF analyses, ME-2 allows full exploration of the rotational ambiguity of the solution space, enabling improved factor separation and a more physically meaningful solution. In the present study, the POA factor mass spectrum was constrained using the $a$-value approach (Canonaco et al., 2013), in which the factor spectrum is allowed to vary from a predefined anchor spectrum by factor of $a$; other factor spectra and all factor time series were unconstrained.

For each experiment, high-resolution and unit-massresolution AMS data from the smog chamber, PAM and MSC were combined into a single data set for PMF analysis. Data uncertainties were estimated according to the method of Allan et al. (2003). Ions mathematically dependent on $\left[\mathrm{CO}_{2}\right]^{+}$ in the AMS analysis process were removed from the data set for the model calculations and manually recalculated afterwards. The anchor mass spectrum for POA was calculated individually for each experiment as the average mass spectrum of the primary aerosol sampled from the smog chamber. The investigated solution space consisted of 1-10 factors and $a$-values from 0 to 0.5 . Within this space, multiple solutions were found for each experiment in which (1) more than $95 \%$ of the organic mass in the smog chamber was contained in the POA factor; (2) the POA factor mass spectrum and time series were highly correlated across solutions; (3) residuals were acceptably low and indicated no mass spectral or temporal regions with significant unexplained features; and (4) all non-POA factors displayed temporal behavior consistent with secondary aerosol formation. From these solutions, the average factor profile and time series were chosen to rep- resent POA. Note that this method cannot distinguish SOA from aged POA, and implicitly assumes that the aging of POA does not exert a significant influence on the ensemble mass spectrum.

\section{Results and discussion}

\section{$3.1 \alpha$-Pinene}

OA yields measured after the PAM ranged from $0.31-0.67$ at $\mathrm{OH}$ exposures of $(0.97-3.3) \times 10^{8}$ molec $\mathrm{cm}^{-3} \mathrm{~h}$ (Fig. 2, Table 1), which are within or exceed the range of those reported by Lambe et al. (2011a) (0.19-0.38 at OH exposures of $\sim(0.06-3) \times 10^{8}$ molec cm $\mathrm{cm}^{-3} \mathrm{~h}$ when reacting 78 $88 \mathrm{ppbv} \alpha$-pinene), Chen et al. (2013) ( $\sim 0.3$ at an OH exposure of $\sim 1.5 \times 10^{8}$ molec $\mathrm{cm}^{-3} \mathrm{~h}$ when reacting $50.5 \mathrm{ppbv}$ $\alpha$-pinene) and Lambe et al. (2015) $(\sim 0.35$ at an $\mathrm{OH}$ exposure of $\sim 1.56 \times 10^{8} \mathrm{molec}^{-3} \mathrm{~h}$ when reacting $41-100 \mathrm{ppbv}$ $\alpha$-pinene) from the photo-oxidation of $\alpha$-pinene in the PAM. The higher yields in these experiments are due to higher $\alpha$ pinene amounts (Kang et al., 2007) and the presence of seed aerosol.

Maximum OA yields determined using the PAM were within a factor of $\sim 1.5$ of those of the SC; however during the same experiments (Fig. 2, Table 1). Chen et al. (2013) and Lambe et al. (2011a) also compared OA yields from the PAM and the SC; however, the PAM and the SC experiments were conducted under significantly different conditions. For example, in the studies by both Chen et al. (2013) and Lambe et al. (2011a), the SC experiments were conducted using seed aerosol, whereas the PAM experiments were not. This is in contrast to the experiments in the current study, where seed aerosol was present in both the SC and the PAM. Despite these differences, Lambe et al. (2011a) observed good agreement between the maximum yields at similar $\mathrm{OH}$ exposures. Chen et al. (2013) measured a $\sim 1.5$ factor difference in yields between the PAM $(\sim 0.3)$ and the $\mathrm{SC}(\sim 0.5)$, although particulate wall losses in the PAM were not taken into account, which would bring these yields into better agreement. The most recent work by Lambe et al. (2015) showed that SOA yields are enhanced by a factor of $\sim 3-5$ in the presence of acidic seed aerosol when oxidizing isoprene in the PAM, although this enhancement is expected to be less for compounds with higher SOA yields, such as $\alpha$-pinene.

Although agreement within a factor of 1.5 between the PAM and the SC is reasonable considering the uncertainties associated with both methods, the PAM yields were consistently lower where direct SC comparisons were available. Lower volatility gases formed from the oxidation of $\alpha$-pinene can undergo several fates including the following: (1) condensation onto the reactor surfaces (e.g., wall and outlet); (2) condensation onto pre-existing aerosol; (3) homogeneous nucleation; and (4) further oxidation in the gas phase. The probability of each of these fates will affect the observed 

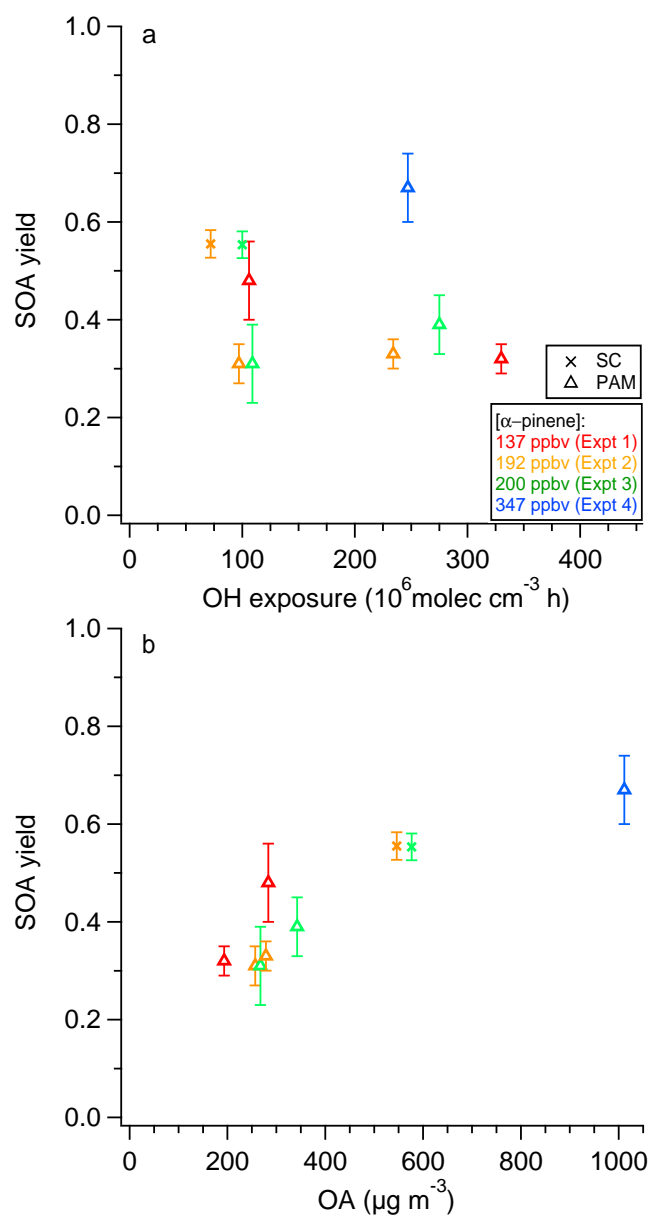

Figure 2. SOA yields determined using the PAM and the SC from $\alpha$-pinene photo-oxidation experiments as a function of (a) $\mathrm{OH}$ exposure and (b) organic aerosol loading. Color designates experiment number and marker shape designates aging device. Legend in (a) also applies to (b).

yields. Although the isolation of each effect is beyond the scope of this work, likely all effects occur to some degree in both the SC and flow reactors.

Particle wall losses in the SC and the PAM were accounted for as described earlier; however, accurate accounting of semi-volatile losses is challenging (Weitkamp et al., 2007; Matsunaga and Ziemann, 2010; Zhang et al., 2014) Zhang et al. (2014) found that when the losses of semi-volatile vapors to chamber walls were not accounted for, $\alpha$-pinene SOA yields were underestimated by a factor of 1.3 and 1.6, under high and low $\mathrm{NO}_{x}$ conditions, respectively. For toluene oxidation, this bias decreased with increasing reactant mixing ratios, as well as with faster oxidation. As $\alpha$-pinene mixing ratios were much higher in these experiments (Table 1) compared to the 46-47 ppbv used by Zhang et al. (2014), these biases are expected to be lower in our study. There is a ring flow along the outer circumference of the cylindrical PAM reactor in an attempt to reduce interaction of the inner sam- ple flow with the walls; however without careful analysis it is not known how much this design actually reduces the effects of the walls on the sampled flow. For example, Lambe et al. (2011a) concluded that wall losses in the PAM have the largest effect on yields. Although the SA / V ratio is higher in the PAM $\left(\sim 18 \mathrm{~m}^{-1}\right)$ than the SC $\left(\sim 3 \mathrm{~m}^{-1}\right)$, the residence time in the PAM is lower, which would decrease the loss of vapors to the walls.

The $\mathrm{OH}$ concentrations in the PAM were significantly higher than in the SC to allow for rapid aging, but the higher $\mathrm{OH}$ concentrations also increases the probability that molecules reach higher oxidation states before condensing. Collisional theory (Atkins and de Paula, 2014) predicts that under the experimental conditions, the probability of colliding with an $\mathrm{OH}$ molecule or with a seed aerosol was on the same order of magnitude in the SC, whereas the probability of colliding with an $\mathrm{OH}$ molecule in the PAM was 3 orders of magnitude greater than the probability of a seed-aerosol collision. Differing product volatility distributions can affect measured yields as more oxygenated/lower volatility products can overcome the Kelvin effect more easily to grow freshly nucleated particles, which would increase yields in the PAM relative to the SC due to an increase in aerosol surface area relative to the walls. The temporal evolution of the particle number concentration in the SC showed a rapid increase when the UV lights were turned on, indicating that there was nucleation (Fig. S2). Although SMPS measurements were not made after the PAM, it is likely nucleation also occurred, as aging is much faster in the PAM. Conversion of mass-based size distributions measured using the AMS to number distributions shows that the number of particles in the PAM were $\sim 2-3$ orders of magnitude greater than in the SC, further indicating that nucleation occurred in the PAM. However, the relatively high gas phase concentrations allowed freshly nucleated particles in both systems to grow despite possible differences in oxidation state. Differences in product volatility can also affect condensation rates. For example, products with sufficiently low volatility may condense irreversibly, whereas higher volatility products may undergo multiple condensation/evaporation events increasing the likelihood of collision with the wall. The resulting size distribution is bimodal (Fig. S3) with one mode corresponding to the seed aerosol and one mode at lower diameters, suggesting that nucleation and condensation on the newly created particles were significant mechanisms for SOA formation in the PAM chamber in these experiments.

As the transmission efficiency of particles in the AMS decreases when $d_{\mathrm{va}}$ is below $\sim 100 \mathrm{~nm}$ and above $\sim 500 \mathrm{~nm}$ (Liu et al., 2007), the measured yields will be lower if there is significant mass outside this optimal AMS transmission range. In the PAM, the mode of the mass-based size distribution of the nucleated particles measured by AMS was at a $d_{\mathrm{va}}$ of $\sim 100 \mathrm{~nm}$, compared to that of the SC (Fig. S3), which was at a $d_{\mathrm{va}}$ of $\sim 230 \mathrm{~nm}$. The distributions also suggest that there were particles greater than $1 \mu \mathrm{m}$ in the SC. It is not possible 
to preclude that significant mass formed in the PAM was below the optimal transmission range of the AMS, which would contribute to lower yields in the PAM compared to the SC, or that significant mass formed in the $\mathrm{SC}$ was above the transmission range, which would lower yields measured in the SC. These differences in the size distributions between the PAM and the SC at both edges of the optimal transmission range of the AMS make measurements with a single instrument difficult and future work to quantitatively measure particles with sizes both above and below the detection range of the AMS would provide further insight.

Increased oxidation, either in the gas phase or through heterogeneous chemistry, can result in fragmentation to form smaller, higher volatility products that partition predominately to the gas phase, resulting in lower aerosol yields (Kroll et al., 2009; Chacon-Madrid and Donahue, 2011; Lambe et al., 2012). Lambe et al. (2011a), Chen et al. (2013), Chhabra et al. (2015) and Lambe et al. (2015) found decreasing yields in the PAM in $\alpha$-pinene oxidation experiments at $\mathrm{OH}$ exposures above $\sim(1.5-2) \times 10^{8}$ molec $\mathrm{cm}^{-3} \mathrm{~h}$, which were attributed to an increasing importance of fragmentation relative to functionalization reactions. As only one experiment was conducted at each reactant mixing ratio, the significance of any trends in yields with $\mathrm{OH}$ exposure is difficult to determine. For example, SOA production from vehicle emissions measured by Tkacik et al. (2014) varied by up to a factor of $\sim 8$ at the same $\mathrm{OH}$ exposure.

In addition to yields, chemical composition is a critical parameter influencing health, visibility and climate. Elemental ratios (oxygen to carbon $(\mathrm{O}: \mathrm{C})$ and hydrogen to carbon $(\mathrm{H}: \mathrm{C})$ ) provide insights into the OA composition and chemical processes occurring with aging (Aiken et al., 2008) (Fig. 3a-d). Another measure of composition is the fraction of $\mathrm{OA}$ signal from $\left[\mathrm{CO}_{2}^{+}\left(f \mathrm{CO}_{2}^{+}\right)\right.$compared to that from $\left[\mathrm{C}_{2} \mathrm{H}_{3} \mathrm{O}\right]^{+}\left(f \mathrm{C}_{2} \mathrm{H}_{3} \mathrm{O}^{+}\right)$determined using AMS data. Carboxylic acids contribute largely to $\left[\mathrm{CO}_{2}\right]^{+}$, whereas $\left[\mathrm{C}_{2} \mathrm{H}_{3} \mathrm{O}\right]^{+}$is largely from compounds containing non-acid oxygenated functionalities, such as carbonyls and alcohols ( $\mathrm{Ng}$ et al., 2011). As the organic signals at $\left[\mathrm{H}_{2} \mathrm{O}\right]^{+}$and $[\mathrm{CO}]^{+}$could not be determined for the present data set (Aiken et al., 2008; Chen et al., 2011), elemental ratios and fractional signals were estimated using the method of Aiken et al. (2008). The triangular space drawn by the lines in Fig. 3e-h shows the region in which ambient measurements typically fall ( $\mathrm{Ng}$ et al., 2010). The data points from $\alpha$-pinene photo-oxidation typically lie on the right-hand side of this plot (Ng et al., 2010; Chhabra et al., 2011; Kang et al., 2011; Lambe et al., 2011b; Pfaffenberger et al., 2013), as also observed here. The space encompassing the data of Pfaffenberger et al. (2013), the only study to report high resolution data, in the $f \mathrm{CO}_{2}^{+}-f \mathrm{C}_{2} \mathrm{H}_{3} \mathrm{O}^{+}$plot are shown in Fig. 3. The $\mathrm{SC}$ and the PAM $f \mathrm{C}_{2} \mathrm{H}_{3} \mathrm{O}^{+}$values were higher than Pfaffenberger et al. (2013), which is likely due to the higher $\alpha$ pinene mixing ratios used here (Kang et al., 2011). In the SC and the PAM, $\mathrm{O}: \mathrm{C}$ and $f \mathrm{CO}_{2}^{+}$generally increased and $\mathrm{H}: \mathrm{C}$
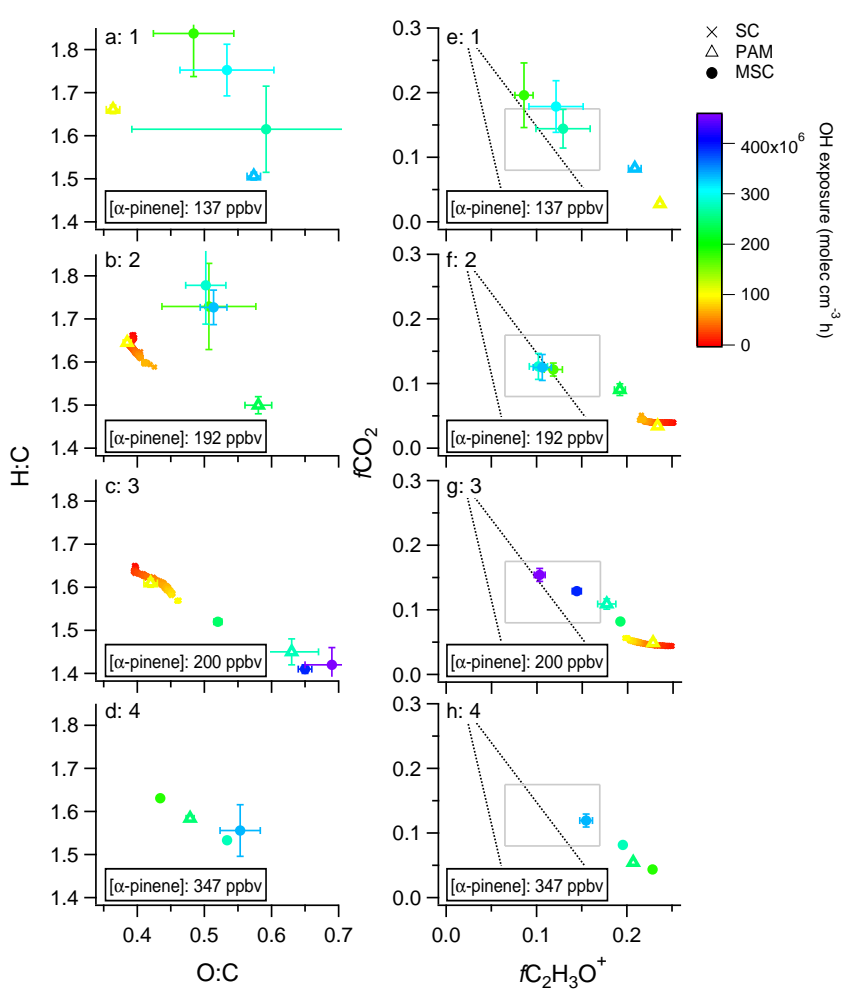

Figure 3. Ratio of $\mathrm{H}: \mathrm{C}$ as a function of $\mathrm{O}: \mathrm{C}$ (a-d, experiments 14 respectively) and the ratio of $\left[\mathrm{CO}_{2}\right]^{+}$to the total organic aerosol as a function of the ratio of $\left[\mathrm{C}_{2} \mathrm{H}_{3} \mathrm{O}\right]^{+}$to the total organic aerosol (e-h, experiments 1-4 respectively) for each $\alpha$-pinene experiment. Color scale indicates $\mathrm{OH}$ exposure. In (e)-(h), dashed lines indicate the region in which ambient $\mathrm{OA}$ measurements typically lie $(\mathrm{Ng}$ et al., 2010) and gray boxes encompass the measurements from Pfaffenberger et al. (2013).

and $f \mathrm{C}_{2} \mathrm{H}_{3} \mathrm{O}^{+}$decreased with increasing $\mathrm{OH}$ exposure, as expected (Fig. 3). Although the PAM aerosol was slightly less oxidized compared to the SC aerosol for the same $\mathrm{OH}$ exposure, for the uncertainties associated with both devices, the agreement between the PAM and the SC in Fig. 3 at comparable $\mathrm{OH}$ exposures is satisfactory.

For the MSC, there was little SOA mass above the optimal transmission range of the AMS (Fig. S3). Nucleation was evident with a mass mode at $\sim 20-30 \mathrm{~nm}$, making it difficult to draw conclusions about the yields determined using the MSC for this system. In the MSC, oxidation was faster and the residence time was significantly shorter than in the PAM. This promotes faster nucleation and reduces the time for particle growth, making particle transmission limitations more significant in the MSC than in the PAM. Although yields are not reported for the MSC, the OA size distributions were mono-modal, suggesting that the particles formed via the same mechanisms and thus the measured composition is considered representative of the bulk SOA. For the MSC, $\mathrm{O}: \mathrm{C}$ and $f \mathrm{CO}_{2}^{+}$increased with increasing $\mathrm{OH}$ exposure in the experiments with the highest $\alpha$-pinene mixing ratios (3 


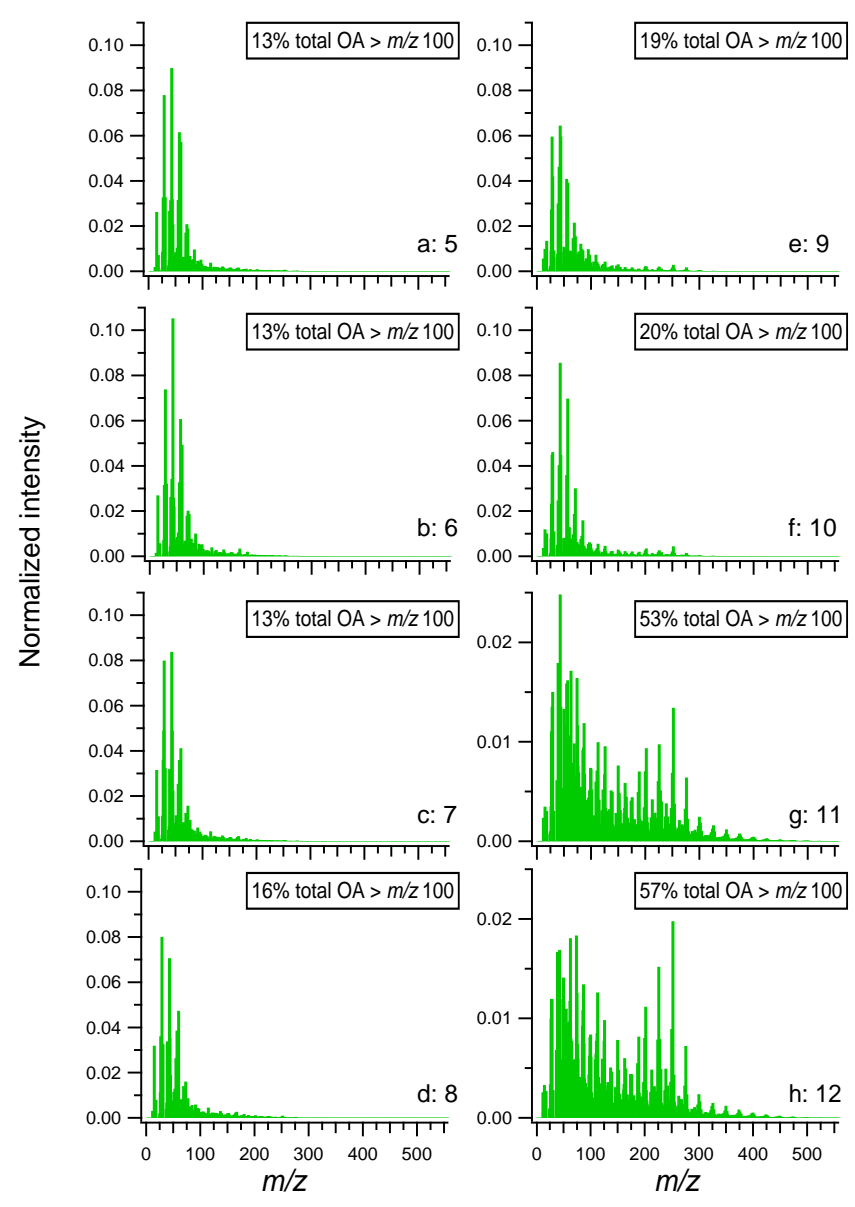

Figure 4. Primary organic aerosol mass spectra normalized to the total organic signal measured by the AMS from the SC for woodcombustion experiments 5-12 (a)-(h). Experiments are ordered according to ascending contribution of mass above $m / z 100$ to the total OA mass, which is given for each experiment.

and 4), as expected. For the two lowest $\alpha$-pinene mixing ratios, the measurement uncertainties are large due to the low mass loadings, so no conclusions were drawn.

The $\mathrm{OH}$ concentration influenced the rate of nucleation and thus the size of the resulting aerosol. At similar $\mathrm{OH}$ exposures, the mode of the largest OA peak in the size distribution was smaller in the PAM than in the SC after aging. The MSC had higher $\mathrm{OH}$ concentrations, a shorter residence time and produced an OA mode at smaller diameters compared to the PAM. Faster oxidation increases the nucleation rate which in turn results in smaller particle sizes. Oxidation rate may even vary within the same system as the $\mathrm{OH}$ concentration increases. As a consequence, it may not be possible to separate the effect of fragmentation from size detection limitations as the $\mathrm{OH}$ concentration increases.

\subsection{Wood combustion}

There was significant variability in POA composition among the wood-combustion experiments, as seen in the mass spectra (Fig. 4). For experiments 11 and 12, the contribution to the total OA mass from ions at higher $m / z$ values (i.e., $m / z>100$ ), which are largely attributable to PAHs (polycyclic aromatic hydrocarbons) (Elsasser et al., 2013; Eriksson et al., 2014; Bruns et al., 2015), was significantly greater than for the other experiments. For example, the contribution of OA above $m / z 100$ to the total OA mass for experiments 11 and 12 was $53-57 \%$, compared to $19-20 \%$ for experiments 9 and 10 , and $13-16 \%$ for experiments $5-8$ (Table $\mathrm{S} 1$ ). The gas phase composition of the primary emissions also varied among experiments. In the PTR-MS mass spectra, signals at $m / z 79,95$ and 129 were attributed largely to aromatic compounds (benzene, phenol and naphthalene, respectively). The sum of these tracers in experiments 11 and 12 contributed 35 and $41 \%$ to the total volatile organic compound (VOC) signal (cps) measured using the PTR-MS, compared to 4 and $17 \%$ in experiments 9 and 10, and $1-2 \%$ to experiments $5-8$.

In the wood-combustion experiments, the modes of the mass-based size distributions were all within the optimal AMS transmission range (Fig. S4), which reduces possible biases in the measured emission factors between the devices due to AMS limitations compared to the $\alpha$-pinene experiments. However, a mode originating from nucleation during aging may have existed but remained undetected by the AMS (Corbin et al., 2015).

In contrast to the $\alpha$-pinene experiments, the maximum total OA emission factors in all wood-combustion experiments were observed with the PAM (Fig. 5, Table 1). OA emission factors as a function of OA mass are shown in Fig. S5. For all experiments except the two with the highest aromatic content (11 and 12), the PAM and the SC maximum emission factors were within a factor of 2 , which is reasonable considering the uncertainties associated with both devices. It is interesting that the emission factors in the PAM were consistently higher compared to the SC, whereas in the $\alpha$-pinene experiments, the yields in the PAM were generally lower compared to the SC. This difference is probably not due to differences in integrated $\mathrm{OH}$ exposure, as the $\mathrm{OA}$ signal in the $\mathrm{SC}$ plateaued at a maximum value by the end of most experiments. Notably, the starting aerosol mass was higher in the PAM compared to the $\alpha$-pinene experiments (Table S1), which reduces wall losses by providing additional surface onto which particles can condense. A shift in the mode of the mass-based size distributions to larger diameters may also have contributed to increases in the measured emission factors from the PAM relative to the SC, although mass may be missed at the upper size range in both the SC and the PAM, as well as at the lower size range in the case of the PAM (Fig. S4).

In the PAM, higher $\mathrm{OH}$ concentrations increase the probability that a compound undergoes further oxidation in the 


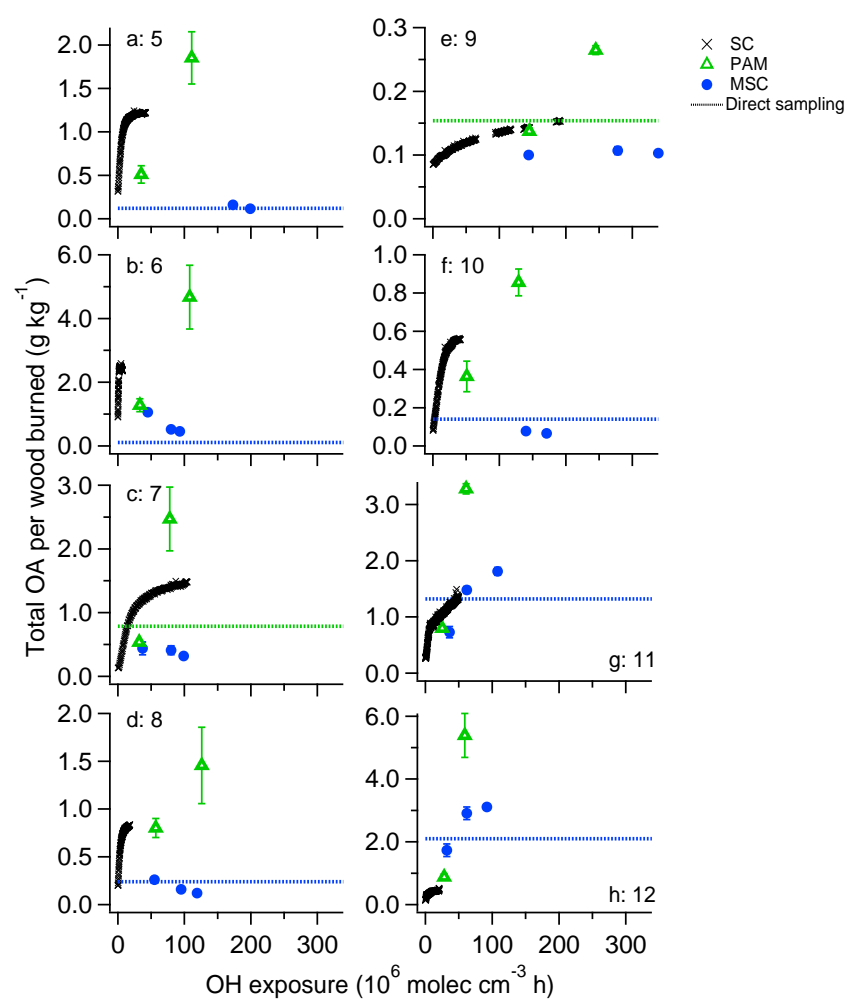

Figure 5. Total organic aerosol after aging normalized to the mass of wood burned as a function of $\mathrm{OH}$ exposure for each woodcombustion experiment (a-h; experiments 5-12). Individual data points correspond to the SC and the PAM and MSC when sampling from the SC and the dashed lines correspond to direct sampling (unknown $\mathrm{OH}$ exposure). For (c) and (e) (experiments 7 and 9), direct sampling corresponds to the PAM and for all other experiments, direct sampling corresponds to the MSC.

gas phase before condensing on a particle or fragmenting to higher volatility products which largely remain in the gas phase. In the two experiments with the highest aromatic content (11 and 12), the emission factors measured from the PAM relative to the SC were largest. This may be due to the fact that aromatic (or other cyclic) organics can undergo ring-opening rather than fragmentation reactions upon carbon-carbon bond breakage (Lim and Ziemann, 2009; Chhabra et al., 2011), which would result in aerosol with less volatile/higher molecular weight products and increased aerosol mass. Slower reaction rates of aromatic compounds with $\mathrm{OH}$ relative to non-aromatic species could also result in less fragmentation on the same oxidation timescale. However, there is a lack of data on non-aromatic species emitted during wood combustion which contribute significantly to SOA formation. VOC mixing ratios were also higher in the high aromatic content experiments (Table S1), which is expected to improve emission factor agreement between the PAM and the SC by increasing partitioning to the particle phase and thus providing additional surface area onto which species can condense. Although the SOA formation pathways in the PAM may be much different than in the atmosphere, previous work has shown that reasonable $\mathrm{O}: \mathrm{C}$ and $\mathrm{H}: \mathrm{C}$ values are achieved in the PAM when compared to ambient measurements (Ortega et al., 2013), which was also observed here, as discussed below.

Although relative PAH concentrations were not high in all experiments, low levels can still contribute significantly to SOA formation. For example, Chan et al. (2009) estimated that gas phase PAHs, despite being only half the concentration of light aromatics, produced four times more SOA during the first $12 \mathrm{~h}$ of oxidation of emissions from the burning of pine wood under normal conditions. However, previous oxidation of PAH reactants in the PAM did not result in higher-than-expected yields compared to literature (Lambe et al., 2011a; Chhabra et al., 2015). For example, Chhabra et al. (2015) found yields from naphthalene photo-oxidation in the PAM ranging from 0.01 to 0.14 , which are lower than expected from literature (Kautzman et al., 2010). However, Chhabra et al. (2015), also observed significantly lower yields in the $\alpha$-pinene system than previous PAM studies, which may be a reflection of the instrumental measurement technique.

For all wood smoke experiments, PAM emission factors increased with increasing $\mathrm{OH}$ exposure indicating that fragmentation was not as significant as functionalization reactions in the PAM. In agreement with this result, Ortega et al. (2013) oxidized emissions from open biomass burning and did not observe a decrease in emission factors with increasing $\mathrm{OH}$ exposure up to a maximum exposure ranging from $5.42 \times 10^{7}$ to $1.58 \times 10^{8}$ molec $\mathrm{cm}^{-3} \mathrm{~h}$ depending on the experiment.

When sampling from the SC, the MSC emission factors were lower than those in the SC by a factor of $1.5-8$ for all experiments except for the two with the highest aromatic content. For the experiments with the highest aromatic content, the maximum emission factors in the MSC were higher than in the SC, which as for the PAM, may be due to the increased ability of aromatics to resist fragmentation to higher volatility products with multiple oxidation steps or higher VOC mixing ratios in these experiments.

At the highest $\mathrm{OH}$ exposure for each experiment, the mode of the measured mass size distribution from the MSC was within the optimal AMS transmission range (Fig. S4), except for experiment 7 which showed a bi-modal distribution with one mode around $100 \mathrm{~nm}$. At lower $\mathrm{OH}$ exposures, there was evidence of bi-modal distributions in some cases (Fig. S4), which may be underestimated in the AMS. Although there is not an obvious mode below a $d_{\mathrm{va}}$ of $\sim 100 \mathrm{~nm}$ at the highest $\mathrm{OH}$ exposure as observed in the $\alpha$-pinene experiments (Fig. S3), except for experiment 7, contributions to the total OA mass from particles below the optimal transmission range of the AMS cannot be excluded.

In addition to possible contribution to the mass from nucleation mode particles not observed with the AMS, other factors may contribute to the reduced yields in the MSC. 
Unlike the PAM, there is no outer ring flow to separate the sample flow from the reactor walls and the MSC SA/V ratio $\left(\sim 200 \mathrm{~m}^{-1}\right)$ is about 10 times higher than the PAM and over 50 times higher than the SC. The temperature inside the MSC is higher than in the PAM, which is expected to reduce the condensation of vapors on the reactor surfaces. However, the temperature drop upon exiting the MSC can result in condensation of gas phase species not only onto the particles, but also on the sample lines, where the $\mathrm{SA} / \mathrm{V}$ ratio is higher than inside the MSC. The heating inside the MSC can also shift the partitioning of material towards the gas phase.

Higher concentrations of starting aerosol (Table S1) are expected to increase emission factors in the MSC relative to the $\mathrm{SC}$, as this provides additional surfaces onto which species can condense. Interestingly, the agreement between the SC and MSC did not improve at higher aerosol concentrations (Figs. S5 and S6b). This may suggest that nucleation was the dominant gas-to-particle conversion mechanism and there was insufficient growth of the particles into the optimal AMS detection range in the MSC and that there was significant loss of material on the surfaces either inside the MSC or afterwards. There was no evidence of a significant mass mode below the optimal AMS transmission range, as observed in the $\alpha$-pinene experiments, although the presence of such a mode cannot be excluded and further measurements including the lower size range are needed. Increased VOC concentrations are also expected to increase emission factors, as this would form larger particles as more material condenses. However, there was no clear trend in emission factor with starting VOC mixing ratio (Fig. S6a) as the majority of the burns produced similar VOC mixing ratios. The emission factors from the MSC increased with increasing $\mathrm{OH}$ exposure in the two experiments with highest aromatic content. However, in the experiments with the lowest VOC and aromatic contributions (5-8), the emission factors from the MSC decreased with increasing $\mathrm{OH}$ exposure, indicating that fragmentation may have been significant. Increased nucleation rates at higher $\mathrm{OH}$ concentrations may have also shifted the particle size distribution towards smaller sizes, which are not transmitted as well in the AMS. Higher $\mathrm{OH}$ exposures in the MSC are obtained by increasing the UV light intensity, which in turn increases the temperature in the reactor. As discussed before, this can shift the partitioning of material towards the gas phase and thus lower yields.

Direct sampling with the MSC and the PAM resulted in emission factors within the range observed when sampling from the SC. For the PAM, the dilution factor compared to SC sampling was roughly the same, and thus emission factors from the two sampling schemes are not expected to vary significantly. The dilution factor in the MSC was $\sim 9$ when direct sampling compared to $\sim 100-250$ when sampling from the SC. Increases in emission factors with increasing primary emission concentrations were not observed here, which may have been due to insufficient $\mathrm{OH}$ exposure or the possibilities described above for the SC sampling.
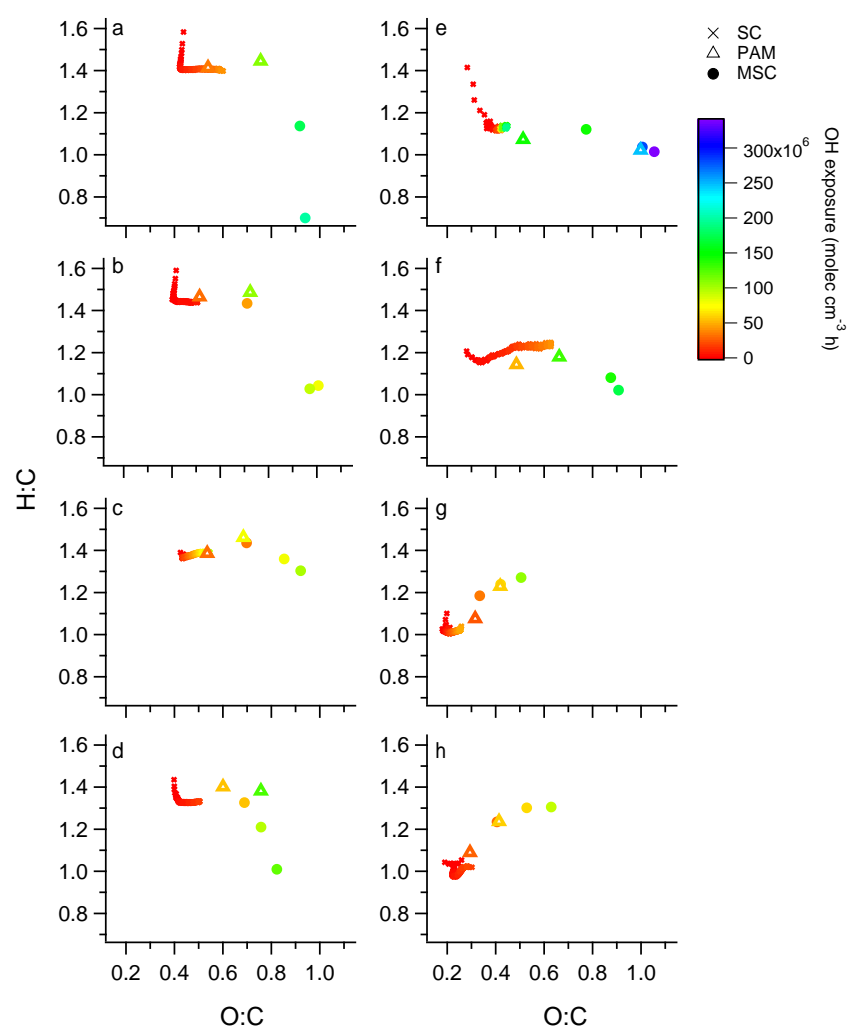

Figure 6. Elemental ratios of SOA generated during each woodburning experiment (a-h, experiments 5-12, respectively) as a function of $\mathrm{OH}$ exposure. Data points correspond to the $\mathrm{SC}$ and the PAM and MSC when sampling from the SC.

The bulk composition of the aged emissions is influenced by composition as well as the relative contributions of POA and SOA to total OA. Figures 6 and 7 compare the elemental ratios and $f \mathrm{CO}_{2}^{+}-f \mathrm{C}_{2} \mathrm{H}_{3} \mathrm{O}^{+}$plot for the SOA generated in each device, determined using PMF as described previously. Figures S7 and S8 show the same plots for the bulk-aged OA. There was reasonable compositional agreement of the SOA generated in the PAM and the SC at similar OH exposures, as observed for $\alpha$-pinene photo-oxidation. At higher $\mathrm{OH}$ exposures, $\mathrm{O}: \mathrm{C}$ increased in the $\mathrm{SC}$ and the PAM to varying degrees, indicating that the bulk SOA composition changed with aging. The increased oxygenation of SOA with aging could be due to the volatility distribution of the primary emissions. For example, products with lower volatility may only require one oxidation step to partition significantly to the particle phase, whereas higher volatility products may require multiple oxidation steps prior to partitioning. In the PAM, an increased likelihood of further oxidation in the gas phase prior to condensing at higher $\mathrm{OH}$ concentrations could also have contributed to changes in SOA composition. Increasing fragmentation relative to functionalization has also been shown to increase O:C (Lambe et al., 2012); however, emission factors in the PAM and the SC increased with increased aging, suggesting functionalization dominated. It 


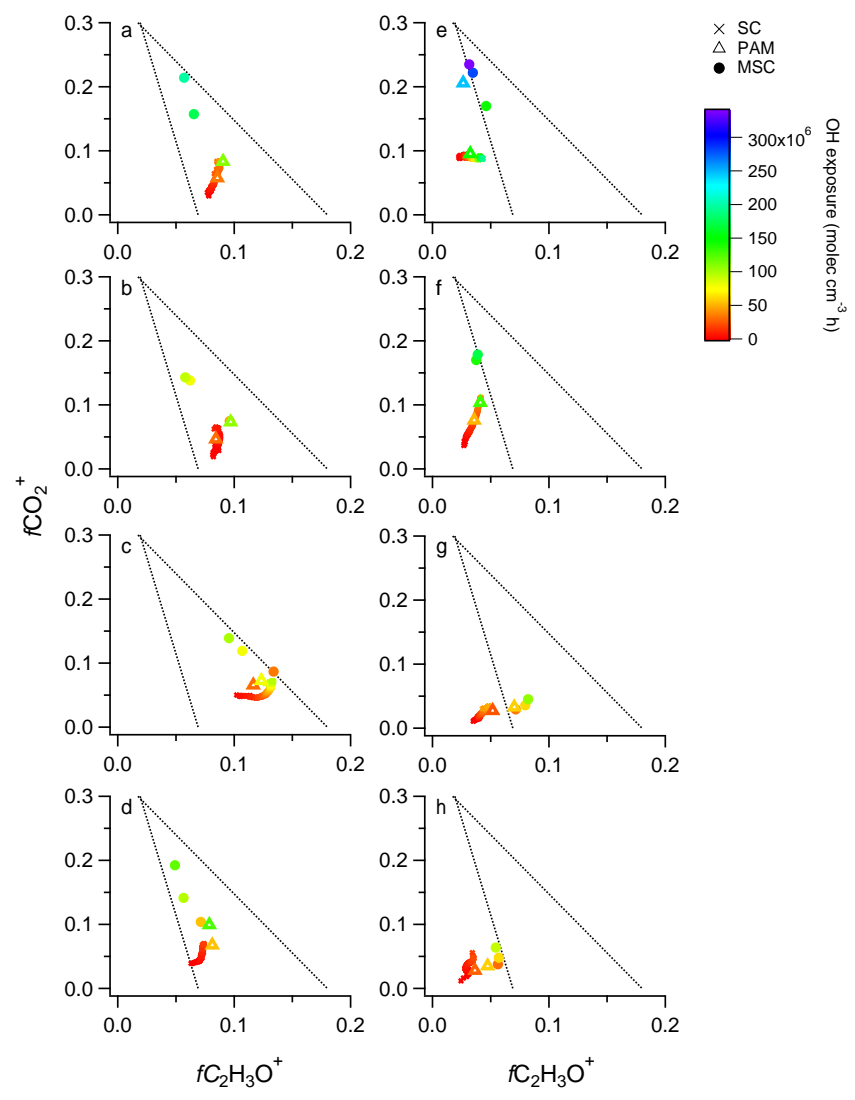

Figure 7. Plot of $f \mathrm{CO}_{2}^{+}$as a function of $\mathrm{fC}_{2} \mathrm{H}_{3} \mathrm{O}^{+}$for SOA generated during each wood-burning experiment (a-h, experiments 512, respectively). Data points correspond to the SC and the PAM and MSC when sampling from the SC.

should be noted that significant particulate $[\mathrm{CO}]^{+}$is expected in the AMS from wood combustion, which would influence reported $\mathrm{O}: \mathrm{C}$ ratios; however, quantification is challenging due to interference from the large $\left[\mathrm{N}_{2}\right]^{+}$signal from air at the same nominal mass (Ortega et al., 2013; Corbin et al., 2015). The standard approach of assuming particulate $[\mathrm{CO}]^{+}$and $\left[\mathrm{CO}_{2}\right]^{+}$are equal was applied here.

In the MSC, $\mathrm{O}: \mathrm{C}$ and $f \mathrm{CO}_{2}^{+}$was higher than in the $\mathrm{SC}$, particularly in the experiments with lower aromatic contributions, although there was typically less overlap in $\mathrm{OH}$ exposure between the systems. Increased oxygenation in the MSC may be due to the higher probability of gas phase oxidation prior to condensation/nucleation in the MSC compared to the SC or increased fragmentation relative to functionalization. In these experiments, the emission factors also decreased with increasing $\mathrm{OH}$ exposure, suggesting fragmentation increased at higher $\mathrm{OH}$ concentrations. Fast oxidation at higher $\mathrm{OH}$ concentrations may also produce smaller particles which fall below the optimum transmission size range of the AMS.

Variation in the SOA mass spectra can be summarized by determining the angle $(\theta)$ between two mass spectral vec-

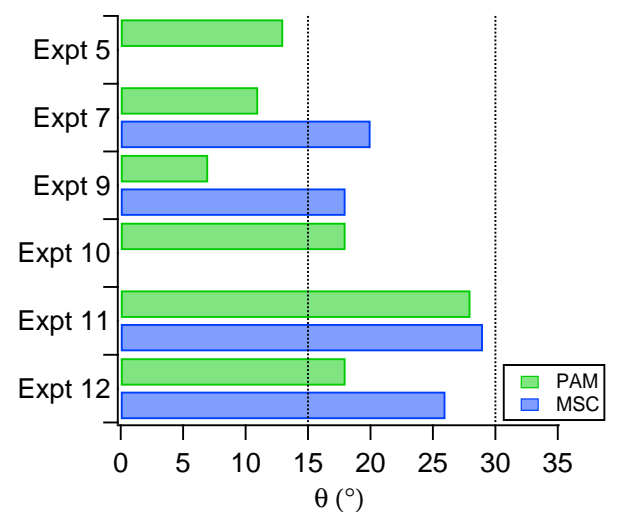

Figure 8. Comparison of PAM and MSC mass spectra to SC mass spectra for SOA generated during each wood-combustion experiment when $\mathrm{OH}$ exposures were within $30 \%$ (Table 1). Theta $(\theta)$, the angle between two mass spectral vectors, describes the degree of similarity between the two mass spectra (Kostenidou et al., 2009). Dashed vertical lines indicate $\theta$ of 15 and $30^{\circ}$. Values of $\theta$ less than $15^{\circ}$ indicate good agreement between the mass spectra, values between 15 and $30^{\circ}$ indicate that there are similarities, but also important differences, and values greater than $30^{\circ}$ indicate poor agreement (Bougiatioti et al., 2014).

tors (Kostenidou et al., 2009). As described by Bougiatioti et al. (2014), $\theta$ values less than $15^{\circ}$ indicate good agreement between mass spectra, values between 15 and $30^{\circ}$ indicate similarities, but also important differences and values greater than $30^{\circ}$ indicate poor agreement. Figure 8 shows $\theta$ for each flow reactor for each experiment compared to the SC when $\mathrm{OH}$ exposures were within $30 \%$. Mass spectral similarities with the SC were greater for the PAM than for the MSC, as expected based on the level of agreement in Figs. 6 and 7. There was generally better agreement between the flow reactors and the SC at lower aromatic fractions, suggesting that the chemistry occurring in the devices is dependent on reactant composition.

\section{Conclusions}

For the first time, the quantities and the chemical composition of organic aerosol generated from the oxidation of $\alpha$ pinene and of wood-combustion emissions with the same precursor mixture were determined using an SC, PAM and MSC. The PAM and the SC agreed reasonably well in terms of quantity and composition for the systems and conditions studied here, considering the challenges associated with both approaches (e.g, wall losses of semi-volatile species). The agreement supports the continued use of the PAM to study atmospheric aging, which is encouraging as it is advantageous due to its portability and its ability to age on the timescale of seconds to minutes. The PAM is also advantageous for simulating extended aging in the atmosphere, which is chal- 
lenging in smog chambers due difficulties in reaching high oxidant exposures.

One concern with the ability of flow reactors to simulate atmospheric processes is that slower processes contributing to the evolution of the particle phase (e.g., condensed phase reactions) are not able to proceed during the relatively short residence time in these flow reactors. However, the similarity in terms of yields and composition shown here between the $\mathrm{SC}$ and the PAM indicate that either these slow processes do not significantly alter bulk aerosol yields or composition or that these slow reactions are accelerated and/or compensated for by the fast oxidation in the PAM.

Discrepancies in yields and emission factors between the MSC and the SC were larger than between the PAM and the $\mathrm{SC}$, possibly due to significant mass below the AMS detection range and/or the design of the MSC (i.e., higher oxidant concentrations leading to fragmentation and insufficient time for condensation of material onto particles inside the reactor). During $\alpha$-pinene experiments, nucleation was observed in all three systems, higher $\mathrm{OH}$ concentrations increased the rate of nucleation and, depending on the residence time, similar $\mathrm{OH}$ exposures produced a range of OA sizes. The slowest system, the SC, produced OA in a size range corresponding to the seed, whereas the PAM and the MSC produced an OA mode smaller than the seed. In the case of the MSC, the fastest system, this mode was below the optimum transmission range of the AMS. For wood-burning experiments, this size dependency was difficult to establish due to the presence of primary OA.

Further work with more comprehensive coverage of the potential particle size range (i.e., include $d_{\mathrm{va}}$ range less than $100 \mathrm{~nm}$ and greater than $1 \mu \mathrm{m}$ ) would improve our understanding of the differences in yields and emissions factors when comparing the MSC to the SC. Determining the sources of discrepancy between the MSC and the SC is critical for determining the applicability of the MSC for OA quantification.

For the wood smoke emissions with the highest aromatic content, the maximum emission factors measured in the MSC and the PAM were largest relative to those measured in the SC, which may be due to the increased ability of aromatics to resist fragmentation to higher volatility products with multiple oxidation steps or higher VOC mixing ratios in these experiments. Further work comparing the yields from oxidation of aromatic species in the flow reactors and the SC would clarify the applicability of flow reactors when analyzing reactants with high aromatic content.

In all cases, the OA loadings, although atmospherically relevant for some parts of the world, were generally high. Complementary work is needed at lower concentrations (e.g., $<50 \mu \mathrm{g} \mathrm{m}^{-3}$ ) to determine the representativeness of atmospheric flow reactor studies across a broader range of atmospheric concentrations.

\section{The Supplement related to this article is available online at doi:10.5194/amt-8-2315-2015-supplement.}

Acknowledgements. The research leading to these results received funding from the European Community's Seventh Framework Programme (FP7/2007-2013) under grant agreement no. 290605 (PSI-FELLOW), from the Competence Center Environment and Sustainability (CCES) (project OPTIWARES) and from the Swiss National Science Foundation (WOOSHI, grant no. 140590). WHB acknowledges support from the NSF (grant no. ATM 085496). The authors also thank René Richter for invaluable technical support.

Edited by: Y. Iinuma

\section{References}

Aiken, A. C., Decarlo, P. F., Kroll, J. H., Worsnop, D. R., Huffman, J. A., Docherty, K. S., Ulbrich, I. M., Mohr, C., Kimmel, J. R., Sueper, D., Sun, Y., Zhang, Q., Trimborn, A., Northway, M., Ziemann, P. J., Canagaratna, M. R., Onasch, T. B., Alfarra, M. R., Prévôt, A. S. H., Dommen, J., Duplissy, J., Metzger, A., Baltensperger, U., and Jimenez, J. L.: O/C and OM/OC ratios of primary, secondary, and ambient organic aerosols with high-resolution time-of-flight aerosol mass spectrometry, Environ. Sci. Technol., 42, 4478-4485, 2008.

Allan, J. D., Jimenez, J. L., Williams, P. I., Alfarra, M. R., Bower, K. N., Jayne, J. T., Coe, H., and Worsnop, D. R.: Quantitative sampling using an Aerodyne aerosol mass spectrometer 1. Techniques of data interpretation and error analysis, J. Geophys. Res.Atmos., 108, 4090, doi:10.1029/2002JD002358, 2003.

Andreae, M. O. and Merlet, P.: Emission of trace gases and aerosols from biomass burning, Global Biogeochem. Cy., 15, 955-966, 2001.

Atkins, P. and de Paula, J.: Physical Chemistry, 10th Edn., Oxford University Press, Oxford, UK, 2014.

Bahreini, R., Middlebrook, A. M., Brock, C. A., de Gouw, J. A., McKeen, S. A., Williams, L. R., Daumit, K. E., Lambe, A. T., Massoli, P., Canagaratna, M .R., Ahmadov, R., Carrasquillo, A. J., Cross, E.S ., Ervens, B., Holloway, J. S., Hunter, J. F., Onasch, T. B., Pollack, I. B., Roberts, J. M., Ryerson, T. B., Warneke, C., Davidovits, P., Worsnop, D. R., and Kroll, J. H.: Mass spectral analysis of organic aerosol formed downwind of the Deepwater Horizon oil spill: Field studies and laboratory confirmations, Environ. Sci. Technol., 46, 8025-8034, 2012.

Baltensperger, U., Dommen, J., Alfarra, R., Duplissy, J., Gaeggeler, K., Metzger, A., Facchini, M. C., Decesari, S., Finessi, E., Reinnig, C., Schott, M., Warnke, J., Hoffmann, T., Klatzer, B., Puxbaum, H., Geiser, M., Savi, M., Lang, D., Kalberer, M., and Geiser, T.: Combined determination of the chemical composition and of health effects of secondary organic aerosols: The POLYSOA project, J. Aerosol Med. Pulm. Drug Deliv., 21, 145154, 2008.

Barmet, P., Dommen, J., DeCarlo, P. F., Tritscher, T., Praplan, A. P., Platt, S. M., Prévôt, A. S. H., Donahue, N. M., and Baltensperger, U.: $\mathrm{OH}$ clock determination by proton transfer reaction mass 
spectrometry at an environmental chamber, Atmos. Meas. Tech., 5, 647-656, doi:10.5194/amt-5-647-2012, 2012.

Bertram, A. K., Ivanov, A. V., Hunter, M., Molina, L. T., and Molina, M. J.: The reaction probability of $\mathrm{OH}$ on organic surfaces of tropospheric interest, J. Phys. Chem. A, 105, 9415-9421, 2001.

Bougiatioti, A., Stavroulas, I., Kostenidou, E., Zarmpas, P., Theodosi, C., Kouvarakis, G., Canonaco, F., Prévôt, A. S. H., Nenes, A., Pandis, S. N., and Mihalopoulos, N.: Processing of biomassburning aerosol in the eastern Mediterranean during summertime, Atmos. Chem. Phys., 14, 4793-4807, doi:10.5194/acp-144793-2014, 2014.

Bruns, E. A., Krapf, M., Orasche, J., Huang, Y., Zimmermann, R., Drinovec, L., Močnik, G., El-Haddad, I., Slowik, J. G., Dommen, J., Baltensperger, U., and Prévôt, A. S. H.: Characterization of primary and secondary wood combustion products generated under different burner loads, Atmos. Chem. Phys., 15, 2825-2841, doi:10.5194/acp-15-2825-2015, 2015.

Burtscher, H., Baltensperger, U., Bukowiecki, N., Cohn, P., Hüglin, C., Mohr, M., Matter, U., Nyeki, S., Schmatloch, V., Streit, N., and Weingartner, E.: Separation of volatile and non-volatile aerosol fractions by thermodesorption: Instrumental development and applications, J. Aerosol Sci., 32, 427-442, 2001.

Canonaco, F., Crippa, M., Slowik, J. G., Baltensperger, U., and Prévôt, A. S. H.: SoFi, an IGOR-based interface for the efficient use of the generalized multilinear engine (ME-2) for the source apportionment: ME-2 application to aerosol mass spectrometer data, Atmos. Meas. Tech., 6, 3649-3661, doi:10.5194/amt6-3649-2013, 2013.

Chacon-Madrid, H. J. and Donahue, N. M.: Fragmentation vs. functionalization: chemical aging and organic aerosol formation, Atmos. Chem. Phys., 11, 10553-10563, doi:10.5194/acp11-10553-2011, 2011.

Chan, A. W. H., Kautzman, K. E., Chhabra, P. S., Surratt, J. D., Chan, M. N., Crounse, J. D., Kürten, A., Wennberg, P. O., Flagan, R. C., and Seinfeld, J. H.: Secondary organic aerosol formation from photooxidation of naphthalene and alkylnaphthalenes: implications for oxidation of intermediate volatility organic compounds (IVOCs), Atmos. Chem. Phys., 9, 3049-3060, doi:10.5194/acp-9-3049-2009, 2009.

Chen, Q., Liu, Y., Donahue, N. M., Shilling, J. E., and Martin, S. T.: Particle-phase chemistry of secondary organic material: modeled compared to measured O:C and $\mathrm{H}: \mathrm{C}$ elemental ratios provide constraints, Environ. Sci. Technol., 45, 4763-4770, 2011.

Chen, S., Brune, W. H., Lambe, A. T., Davidovits, P., and Onasch, T. B.: Modeling organic aerosol from the oxidation of $\alpha$-pinene in a Potential Aerosol Mass (PAM) chamber, Atmos. Chem. Phys., 13, 5017-5031, doi:10.5194/acp-13-5017-2013, 2013.

Chhabra, P. S., Lambe, A. T., Canagaratna, M. R., Stark, H., Jayne, J. T., Onasch, T. B., Davidovits, P., Kimmel, J. R., and Worsnop, D. R.: Application of high-resolution time-of-flight chemical ionization mass spectrometry measurements to estimate volatility distributions of $\alpha$-pinene and naphthalene oxidation products, Atmos. Meas. Tech., 8, 1-18, doi:10.5194/amt-8-1-2015, 2015.

Chhabra, P. S., Ng, N. L., Canagaratna, M. R., Corrigan, A. L., Russell, L. M., Worsnop, D. R., Flagan, R. C., and Seinfeld, J. H.: Elemental composition and oxidation of chamber organic aerosol, Atmos. Chem. Phys., 11, 8827-8845, doi:10.5194/acp-11-8827$2011,2011$.
Cocker, D. R., Flagan, R. C., and Seinfeld, J. H.: State-of-the-art chamber facility for studying atmospheric aerosol chemistry, Environ. Sci. Technol., 35, 2594-2601, 2001.

Corbin, J. C., Keller, A., Sierau, B., Lohmann, U., and Mensah, A. A.: Organic emissions from a wood stove and a pellet stove before and after simulated atmospheric aging, Aerosol Sci. Technol., accepted, 2015.

Craven, J. S., Yee, L. D., Ng, N. L., Canagaratna, M. R., Loza, C. L., Schilling, K. A., Yatavelli, R. L. N., Thornton, J. A., Ziemann, P. J., Flagan, R. C., and Seinfeld, J. H.: Analysis of secondary organic aerosol formation and aging using positive matrix factorization of high-resolution aerosol mass spectra: application to the dodecane low- $\mathrm{NO}_{\mathrm{x}}$ system, Atmos. Chem. Phys., 12, 1179511817, doi:10.5194/acp-12-11795-2012, 2012.

Cubison, M. J., Ortega, A. M., Hayes, P. L., Farmer, D. K., Day, D., Lechner, M. J., Brune, W. H., Apel, E., Diskin, G. S., Fisher, J. A., Fuelberg, H. E., Hecobian, A., Knapp, D. J., Mikoviny, T., Riemer, D., Sachse, G. W., Sessions, W., Weber, R. J., Weinheimer, A. J., Wisthaler, A., and Jimenez, J. L.: Effects of aging on organic aerosol from open biomass burning smoke in aircraft and laboratory studies, Atmos. Chem. Phys., 11, 12049-12064, doi:10.5194/acp-11-12049-2011, 2011.

DeCarlo, P. F., Kimmel, J. R., Trimborn, A., Northway, M. J., Jayne, J. T., Aiken, A. C., Gonin, M., Fuhrer, K., Horvath, T., Docherty, K. S., Worsnop, D. R., and Jimenez, J. L.: Field-deployable, high-resolution, time-of-flight aerosol mass spectrometer, Anal. Chem., 78, 8281-8289, 2006.

DeCarlo, P. F., Slowik, J. G., Worsnop, D. R., Davidovits, P., and Jimenez, J. L.: Particle morphology and density characterization by combined mobility and aerodynamic diameter measurements. Part 1: theory, Aerosol Sci. Technol., 38, 1185-1205, 2004.

Elsasser, M., Busch, C., Orasche, J., Schön, C., Hartmann, H., Schnelle-Kreis, J., and Zimmermann, R.: Dynamic changes of the aerosol composition and concentration during different burning phases of wood combustion, Energ. Fuels, 27, 4959-4968, 2013.

Eriksson, A. C., Nordin, E. Z., Nyström, R., Pettersson, E., Swietlicki, E., Bergvall, C., Westerholm, R., Boman, C., and Pagels, J. H.: Particulate PAH emissions from residential biomass combustion: Time-resolved analysis with aerosol mass spectrometry, Environ. Sci. Technol., 48, 7143-7150, 2014.

Esteve, W., Budzinski, H., and Villenave, E.: Relative rate constants for the heterogeneous reactions of $\mathrm{OH}, \mathrm{NO}_{2}$ and $\mathrm{NO}$ radicals with polycyclic aromatic hydrocarbons adsorbed on carbonaceous particles. Part 1: PAHs adsorbed on 1-2 $\mu \mathrm{m}$ calibrated graphite particles, Atmos. Environ., 38, 6063-6072, 2004.

Ezell, M. J., Johnson, S. N., Yu, Y., Perraud, V., Bruns, E. A., Alexander, M. L., Zelenyuk, A., Dabdub, D., and Finlayson-Pitts, B. J.: A new aerosol flow system for photochemical and thermal studies of tropospheric aerosols, Aerosol Sci. Technol., 44, 329338, 2010.

George, I. J., Vlasenko, A., Slowik, J. G., Broekhuizen, K., and Abbatt, J. P. D.: Heterogeneous oxidation of saturated organic aerosols by hydroxyl radicals: uptake kinetics, condensed-phase products, and particle size change, Atmos. Chem. Phys., 7, 41874201, doi:10.5194/acp-7-4187-2007, 2007.

Hearn, J. D. and Smith, G. A.: Ozonolysis of mixed oleic acid/n-docosane particles: The roles of phase, morphology, and metastable states, J. Phys. Chem. A, 111, 11059-11065, 2007. 
Hennigan, C. J., Miracolo, M. A., Engelhart, G. J., May, A. A., Presto, A. A., Lee, T., Sullivan, A. P., McMeeking, G. R., Coe, H., Wold, C. E., Hao, W.-M., Gilman, J. B., Kuster, W. C., de Gouw, J., Schichtel, B. A., Collett Jr., J. L., Kreidenweis, S. M., and Robinson, A. L.: Chemical and physical transformations of organic aerosol from the photo-oxidation of open biomass burning emissions in an environmental chamber, Atmos. Chem. Phys., 11, 7669-7686, doi:10.5194/acp-11-7669-2011, 2011.

Heringa, M. F., DeCarlo, P. F., Chirico, R., Tritscher, T., Dommen, J., Weingartner, E., Richter, R., Wehrle, G., Prévôt, A. S. H., and Baltensperger, U.: Investigations of primary and secondary particulate matter of different wood combustion appliances with a high-resolution time-of-flight aerosol mass spectrometer, Atmos. Chem. Phys., 11, 5945-5957, doi:10.5194/acp-11-59452011, 2011.

Hodzic, A., Madronich, S., Kasibhatla, P. S., Tyndall, G., Aumont, B., Jimenez, J. L., Lee-Taylor, J., and Orlando, J.: Organic photolysis reactions in tropospheric aerosols: effect on secondary organic aerosol formation and lifetime, Atmos. Chem. Phys. Discuss., 15, 8113-8149, doi:10.5194/acpd-15-8113-2015, 2015.

IPCC, 2013: Climate Change 2013: The Physical Science Basis. Contribution of Working Group I to the Fifth Assessment Report of the Intergovernmental Panel on Climate Change, edited by: Stocker, T. F., Qin, D., Plattner, G.-K., Tignor, M., Allen, S. K., Boschung, J., Nauels, A., Xia, Y., Bex, V., and Midgley, P. M., Cambridge University Press, Cambridge, UK and New York, NY, USA.

Kang, E., Root, M. J., Toohey, D. W., and Brune, W. H.: Introducing the concept of Potential Aerosol Mass (PAM), Atmos. Chem. Phys., 7, 5727-5744, doi:10.5194/acp-7-5727-2007, 2007.

Kang, E., Toohey, D. W., and Brune, W. H.: Dependence of SOA oxidation on organic aerosol mass concentration and $\mathrm{OH}$ exposure: experimental PAM chamber studies, Atmos. Chem. Phys., 11, 1837-1852, doi:10.5194/acp-11-1837-2011, 2011.

Kautzman, K. E., Surratt, J. D., Chan, M. N., Chan, A. W. H., Hersey, S. P., Chhabra, P. S., Dalleska, N. F., Wennberg, P. O., Flagan, R. C. and Seinfeld, J. H.: Chemical composition of gasand aerosol-phase products from the photooxidation of naphthalene, J. Phys. Chem. A, 114, 913-934, 2010.

Keller, A. and Burtscher, H.: A continuous photo-oxidation flow reactor for a defined measurement of the SOA formation potential of wood burning emissions, J. Aerosol Sci., 49, 9-20, 2012.

Kostenidou, E., Lee, B.-H., Engelhart, G. J., Pierce, J. R., and Pandis, S. N.: Mass spectra deconvolution of low, medium, and high volatility biogenic secondary organic aerosol, Environ. Sci. Technol., 43, 4884-4889, 2009.

Kroll, J. H., Smith, J. D., Che, D. L., Kessler, S. H., Worsnop, D. R., and Wilson, K. R.: Measurement of fragmentation and functionalization pathways in the heterogeneous oxidation of oxidized organic aerosol, Phys. Chem. Chem. Phys., 11, 8005-8014, 2009.

Lambe, A. T., Ahern, A. T., Williams, L. R., Slowik, J. G., Wong, J. P. S., Abbatt, J. P. D., Brune, W. H., Ng, N. L., Wright, J. P., Croasdale, D. R., Worsnop, D. R., Davidovits, P., and Onasch, T. B.: Characterization of aerosol photooxidation flow reactors: heterogeneous oxidation, secondary organic aerosol formation and cloud condensation nuclei activity measurements, Atmos. Meas. Tech., 4, 445-461, doi:10.5194/amt-4-445-2011, $2011 \mathrm{a}$.

Lambe, A. T., Onasch, T. B., Massoli, P., Croasdale, D. R., Wright, J. P., Ahern, A. T., Williams, L. R., Worsnop, D. R., Brune, W. H., and Davidovits, P.: Laboratory studies of the chemical composition and cloud condensation nuclei $(\mathrm{CCN})$ activity of secondary organic aerosol (SOA) and oxidized primary organic aerosol (OPOA), Atmos. Chem. Phys., 11, 8913-8928, doi:10.5194/acp11-8913-2011, 2011b.

Lambe, A. T., Onasch, T. B., Croasdale, D. R., Wright, J. P., Martin, A. T., Franklin, J. P., Massoli, P., Kroll, J. H., Canagaratna, M. R., Brune, W. H., Worsnop, D. R., and Davidovits, P.: Transitions from functionalization to fragmentation reactions of laboratory secondary organic aerosol (SOA) generated from the $\mathrm{OH}$ oxidation of alkane precursors, Environ. Sci. Technol., 46, 5430-5437, 2012.

Lambe, A. T., Cappa, C. D., Massoli, P., Onasch, T. B., Forestieri, S. D., Martin, A. T., Cummings, M. J., Croasdale, D. R., Brune, W. H., Worsnop, D. R. and Davidovits, P.: Relationship between oxidation level and optical properties of secondary organic aerosol, Environ. Sci. Technol., 47, 6349-6357, 2013.

Lambe, A. T., Chhabra, P. S., Onasch, T. B., Brune, W. H., Hunter, J. F., Kroll, J. H., Cummings, M. J., Brogan, J. F., Parmar, Y., Worsnop, D. R., Kolb, C. E., and Davidovits, P.: Effect of oxidant concentration, exposure time, and seed particles on secondary organic aerosol chemical composition and yield, Atmos. Chem. Phys., 15, 3063-3075, doi:10.5194/acp-15-3063-2015, 2015.

Lanz, V. A., Alfarra, M. R., Baltensperger, U., Buchmann, B., Hueglin, C., and Prévôt, A. S. H.: Source apportionment of submicron organic aerosols at an urban site by factor analytical modelling of aerosol mass spectra, Atmos. Chem. Phys., 7, 15031522, doi:10.5194/acp-7-1503-2007, 2007.

Lee, S.-B., Bae, G.-N. and Moon, K.-C.: Smog chamber measurements, in: Atmospheric and Biological Environmental Monitoring, edited by: Kim, Y., Platt, U., Gu, M., and Iwahashi, H., Springer Netherlands, 105-136, 2009.

Li, R., Palm, B. B., Borbon, A., Graus, M., Warneke, C., Ortega, A. M., Day, D. A., Brune, W. H., Jimenez, J. L., and de Gouw, J. A.: Laboratory studies on secondary organic aerosol formation from crude oil vapors, Environ. Sci. Technol., 47, 12566-12574, 2013.

Lim, Y. B. and Ziemann, P. J.: Chemistry of secondary organic aerosol formation from $\mathrm{OH}$ radical-initiated reactions of linear, branched, and cyclic alkanes in the presence of $\mathrm{NO}_{x}$, Aerosol Sci. Technol., 43, 604-619, 2009.

Liu, P. S. K., Deng, R., Smith, K. A., Williams, L. R., Jayne, J. T., Canagaratna, M. R., Moore, K., Onasch, T. B., Worsnop, D. R., and Deshler, T.: Transmission efficiency of an aerodynamic focusing lens system: Comparison of model calculations and laboratory measurements for the Aerodyne aerosol mass spectrometer, Aerosol Sci. Technol., 41, 721-733, 2007.

Massoli, P., Lambe, A. T., Ahern, A. T., Williams, L. R., Ehn, M., Mikkilä, J., Canagaratna, M. R., Brune, W. H., Onasch, T. B., Jayne, J. T., Petäjä, T., Kulmala, M., Laaksonen, A., Kolb, C. E., Davidovits, P., and Worsnop, D. R.: Relationship between aerosol oxidation level and hygroscopic properties of laboratory generated secondary organic aerosol (SOA) particles, Geophys Res. Lett., 37, L24801, doi:10.1029/2010GL045258, 2010.

Matsunaga, A. and Ziemann, P. J.: Gas-wall partitioning of organic compounds in a Teflon film chamber and potential effects on reaction product and aerosol yield measurements, Aerosol Sci. Technol., 44, 881-892, 2010. 
McMurry, P. H. and Grosjean, D.: Gas and aerosol wall losses in Teflon film smog chambers, Environ. Sci. Technol., 19, 11761182, 1985.

McMurry, P. H. and Rader, D. J.: Aerosol wall losses in electrically charged chambers, Aerosol Sci. Technol., 4, 249-268, 1985.

McNeill, V. F., Yatavelli, R. L. N., Thornton, J. A., Stipe, C. B., and Landgrebe, O.: Heterogeneous $\mathrm{OH}$ oxidation of palmitic acid in single component and internally mixed aerosol particles: vaporization and the role of particle phase, Atmos. Chem. Phys., 8, 5465-5476, doi:10.5194/acp-8-5465-2008, 2008.

Ng, N. L., Canagaratna, M. R., Jimenez, J. L., Chhabra, P. S., Seinfeld, J. H., and Worsnop, D. R.: Changes in organic aerosol composition with aging inferred from aerosol mass spectra, Atmos. Chem. Phys., 11, 6465-6474, doi:10.5194/acp-11-64652011, 2011.

Ng, N. L., Canagaratna, M. R., Zhang, Q., Jimenez, J. L., Tian, J., Ulbrich, I. M., Kroll, J. H., Docherty, K. S., Chhabra, P. S., Bahreini, R., Murphy, S. M., Seinfeld, J. H., Hildebrandt, L., Donahue, N. M., DeCarlo, P. F., Lanz, V. A., Prévôt, A. S. H., Dinar, E., Rudich, Y., and Worsnop, D. R.: Organic aerosol components observed in Northern Hemispheric datasets from Aerosol Mass Spectrometry, Atmos. Chem. Phys., 10, 46254641, doi:10.5194/acp-10-4625-2010, 2010.

Ng, N. L., Chhabra, P. S., Chan, A. W. H., Surratt, J. D., Kroll, J. H., Kwan, A. J., McCabe, D. C., Wennberg, P. O., Sorooshian, A., Murphy, S. M., Dalleska, N. F., Flagan, R. C., and Seinfeld, J. H.: Effect of $\mathrm{NO}_{\mathrm{x}}$ level on secondary organic aerosol (SOA) formation from the photooxidation of terpenes, Atmos. Chem. Phys., 7, 5159-5174, doi:10.5194/acp-7-5159-2007, 2007.

Ortega, A. M., Day, D. A., Cubison, M. J., Brune, W. H., Bon, D., de Gouw, J. A., and Jimenez, J. L.: Secondary organic aerosol formation and primary organic aerosol oxidation from biomass-burning smoke in a flow reactor during FLAME-3, Atmos. Chem. Phys., 13, 11551-11571, doi:10.5194/acp-1311551-2013, 2013.

Paatero, P.: Least squares formulation of robust non-negative factor analysis, Chemometr. Intell. Lab., 37, 23-35, 1997.

Paatero, P.: The multilinear engine - a table driven, least squares program for solving multilinear problems, including the n-way parallel factor analysis model, J. Comp. Graph. Stat., 8, 854-888, 1999.

Paatero, P. and Tapper, U.: Positive matrix factorization: A nonnegative factor model with optimal utilization of error estimates of data values, Environmetrics, 5, 111-126, 1994.

Paulsen, D., Dommen, J., Kalberer, M., Prévôt, A. S. H., Richter, R., Sax, M., Steinbacher, M., Weingartner, E., and Baltensperger, U.: Secondary organic aerosol formation by irradiation of 1,3,5trimethylbenzene- $\mathrm{NO}_{x}-\mathrm{H}_{2} \mathrm{O}$ in a new reaction chamber for atmospheric chemistry and physics, Environ. Sci. Technol., 39, 2668-2678, 2005.

Pfaffenberger, L., Barmet, P., Slowik, J. G., Praplan, A. P., Dommen, J., Prévôt, A. S. H., and Baltensperger, U.: The link between organic aerosol mass loading and degree of oxygenation: an $\alpha$ pinene photooxidation study, Atmos. Chem. Phys., 13, 64936506, doi:10.5194/acp-13-6493-2013, 2013.

Platt, S. M., El Haddad, I., Zardini, A. A., Clairotte, M., Astorga, C., Wolf, R., Slowik, J. G., Temime-Roussel, B., Marchand, N., Ježek, I., Drinovec, L., Močnik, G., Möhler, O., Richter, R., Barmet, P., Bianchi, F., Baltensperger, U., and Prévôt, A.
S. H.: Secondary organic aerosol formation from gasoline vehicle emissions in a new mobile environmental reaction chamber, Atmos. Chem. Phys., 13, 9141-9158, doi:10.5194/acp-13-91412013, 2013.

Pope, C. A. and Dockery, D. W.: Health effects of fine particulate air pollution: Lines that connect, J. Air Waste Manage., 56, 709742, 2006.

Presto, A. A., Huff Hartz, K. E., and Donahue, N. M.: Secondary organic aerosol production from terpene ozonolysis. 1. Effect of UV radiation, Environ. Sci. Technol., 39, 7036-7045, 2005.

Presto, A. A., Nguyen, N. T., Ranjan, M., Reeder, A. J., Lipsky, E. M., Hennigan, C. J., Miracolo, M. A., Riemer, D. D., and Robinson, A. L.: Fine particle and organic vapor emissions from staged tests of an in-use aircraft engine, Atmos. Environ., 45, 3603-3612, 2011.

Renbaum, L. H. and Smith, G. D.: Artifacts in measuring aerosol uptake kinetics: the roles of time, concentration and adsorption, Atmos. Chem. Phys., 11, 6881-6893, doi:10.5194/acp-11-68812011, 2011.

Rohrer, F., Bohn, B., Brauers, T., Brüning, D., Johnen, F.-J., Wahner, A., and Kleffmann, J.: Characterisation of the photolytic HONO-source in the atmosphere simulation chamber SAPHIR, Atmos. Chem. Phys., 5, 2189-2201, doi:10.5194/acp-5-21892005, 2005.

Saukko, E., Lambe, A. T., Massoli, P., Koop, T., Wright, J. P., Croasdale, D. R., Pedernera, D. A., Onasch, T. B., Laaksonen, A., Davidovits, P., Worsnop, D. R., and Virtanen, A.: Humiditydependent phase state of SOA particles from biogenic and anthropogenic precursors, Atmos. Chem. Phys., 12, 7517-7529, doi:10.5194/acp-12-7517-2012, 2012.

Smith, J. D., Kroll, J. H., Cappa, C. D., Che, D. L., Liu, C. L., Ahmed, M., Leone, S. R., Worsnop, D. R., and Wilson, K. R.: The heterogeneous reaction of hydroxyl radicals with submicron squalane particles: a model system for understanding the oxidative aging of ambient aerosols, Atmos. Chem. Phys., 9, 3209-3222, doi:10.5194/acp-9-3209-2009, 2009.

Taira, M. and Kanda, Y.: Continuous generation system for lowconcentration gaseous nitrous-acid, Anal. Chem., 62, 630-633, 1990.

Tkacik, D. S., Lambe, A. T., Jathar, S., Li, X., Presto, A. A., Zhao, Y., Blake, D., Meinardi, S., Jayne, J. T., Croteau, P. L., and Robinson, A. L.: Secondary organic aerosol formation from inuse motor vehicle emissions using a potential aerosol mass reactor, Environ. Sci. Technol., 48, 11235-11242, 2014.

Turpin, B. J. and Lim, H.-J.: Species contributions to PM2.5 mass concentrations: revisiting common assumptions for estimating organic mass, Aerosol Sci. Technol., 35, 602-610, 2001.

Wang, B., Lambe, A. T., Massoli, P., Onasch, T. B., Davidovits, P., Worsnop, D. R., and Knopf, D. A.: The deposition ice nucleation and immersion freezing potential of amorphous secondary organic aerosol: Pathways for ice and mixedphase cloud formation, J. Geophys. Res.-Atmos., 117, D16209, doi:16210.11029/12012JD018063, 2012.

Weitkamp, E. A., Sage, A. M., Pierce, J. R., Donahue, N. M., and Robinson, A. L.: Organic aerosol formation from photochemical oxidation of diesel exhaust in a smog chamber, Environ. Sci. Technol., 41, 6969-6975, 2007.

Went, F. W.: Blue hazes in the atmosphere, Nature, 187, 641-643, 1960. 
Zhang, Q., Jimenez, J., Canagaratna, M., Ulbrich, I., Ng, N., Worsnop, D., and Sun, Y.: Understanding atmospheric organic aerosols via factor analysis of aerosol mass spectrometry: a review, Anal. Bioanal. Chem., 401, 3045-3067, 2011.

Zhang, Q., Jimenez, J. L., Canagaratna, M. R., Allan, J. D., Coe, H., Ulbrich, I., Alfarra, M. R., Takami, A., Middlebrook, A. M., Sun, Y. L., Dzepina, K., Dunlea, E., Docherty, K., DeCarlo, P. F., Salcedo, D., Onasch, T., Jayne, J. T., Miyoshi, T., Shimono, A., Hatakeyama, S., Takegawa, N., Kondo, Y., Schneider, J., Drewnick, F., Borrmann, S., Weimer, S., Demerjian, K., Williams, P., Bower, K., Bahreini, R., Cottrell, L., Griffin, R. J., Rautiainen, J., Sun, J. Y., Zhang, Y. M., and Worsnop, D. R.: Ubiquity and dominance of oxygenated species in organic aerosols in anthropogenically-influenced Northern Hemisphere midlatitudes, Geophys. Res. Lett., 34, L13801, doi:10.1029/2007GL029979, 2007.
Zhang, X., Cappa, C. D., Jathar, S. H., McVay, R. C., Ensberg, J. J., Kleeman, M. J., and Seinfeld, J. H.: Influence of vapor wall loss in laboratory chambers on yields of secondary organic aerosol, $\mathrm{P}$. Natl. Acad. Sci. USA, 111, 5802-5807, 2014. 